\title{
The Impact of Biosurfactants on Microbial Cell Properties Leading to Hydrocarbon Bioavailability Increase
}

\author{
Ewa Kaczorek*(D), Amanda Pacholak ${ }^{(D)}$, Agata Zdarta ${ }^{(D)}$ and Wojciech Smułek \\ Institute of Chemical Technology and Engineering, Faculty of Chemical Technology, \\ Poznan University of Technology, 4 Berdychowo Street, 60-965 Poznań, Poland; \\ amanda.d.pacholak@doctorate.put.poznan.pl (A.P.); agata.zdarta@doctorate.put.poznan.pl (A.Z.); \\ wojciech.smulek@put.poznan.pl (W.S.) \\ * Correspondence: ewa.kaczorek@put.poznan.pl; Tel.: +48-61-665-3671
}

Received: 1 August 2018; Accepted: 23 August 2018; Published: 26 August 2018

\begin{abstract}
The environment pollution with hydrophobic hydrocarbons is a serious problem that requires development of efficient strategies that would lead to bioremediation of contaminated areas. One of the common methods used for enhancement of biodegradation of pollutants is the addition of biosurfactants. Several mechanisms have been postulated as responsible for hydrocarbons bioavailability enhancement with biosurfactants. They include solubilization and desorption of pollutants as well as modification of bacteria cell surface properties. The presented review contains a wide discussion of these mechanisms in the context of alteration of bioremediation efficiency with biosurfactants. It brings new light to such a complex and important issue.
\end{abstract}

Keywords: bacteria; biodegradation; biosurfactants; hydrocarbons; hydrophobic pollutants; membrane permeability; rhamnolipids; zeta potential

\section{Introduction}

The last decades have brought ever-increasing oil exploration and processing. Global transport is still based on oil-derived fuels, and additionally, the production of plastics absorbs a considerable amount of hydrocarbons. As a consequence, the transport and processing of crude oil and its derivatives is one of the large-scale industry branches [1-3]. The inevitable consequence is the high risk of the natural environment contamination with petroleum compounds [4]. Pollution caused by many various hydrocarbon substances has become an urgent environmental problem. Occurring frequently in large sizes, ecological disasters show how important it is to have appropriate techniques helpful in fast remediation of the polluted environment. Hydrocarbons removal with physicochemical methods is usually costly and ineffective. The processes of biological decomposition of hydrocarbons in the environment are relatively slow [3]. The main reason for this is the low bioavailability of hydrocarbons to the microorganisms that are capable of using them as a source of carbon and energy [5]. In the field of environmental protection, bioavailability is measured as the amount of a chemical compound (pollutant) that can be collected and decomposed by microorganisms. Accordingly, if the bioavailability of a compound is high under given conditions, its biodegradation is limited only by the rate of chemical reactions that make up the biodegradation pathway [6]. Low bioavailability of hydrocarbons is connected with their low solubility in water as well as their hydrophobic properties. Hydrocarbons have high affinity to soil particulates, sediments, and organic matter, and their solubility in water is relatively low. In turn, the functioning of microbial cells is to a large extent dependent on the aquatic environment [7]. What is more, the bioavailability of hydrophobic petroleum hydrocarbons, due to 
their low water solubility, is limited. These compounds can also adsorb onto the soil matrix, which may result in a decrease in biodegradation efficiency $[8,9]$.

One of the adaptive features of microorganisms capable to degradation of hydrophobic compounds, may be the production of substances showing surface-active propertiesbiosurfactants [10-12]. Microorganisms produce many extracellular compounds that exhibit surface active properties. Among them, several main groups of compounds can be indicated, classified according to their chemical structure. The first, most widespread and most commonly used in the industry group are glycolipids. Their best-known representatives are rhamnolipids produced mainly by Pseudomonas aeruginosa strains [13] and trehalolipids. The latter are composed of disaccharide trehalose linked to mycolic acids (i.e., long-chain $\alpha$-branched- $\beta$-hydroxy fatty acids). They are mainly produced by Gram positive bacteria such as Mycobacterium, Corynebacterium, and Nocardia. Additionally, sophorolipids are an important class of biosurfactants from the group of glycolipids. Their main source is from strains of the Candida genera [14]. The second group of biosurfactants are lipopeptides, produced by Bacillus strains. Their best-known representative is surfactin, produced by strains like B. subtilis [15]. The other groups of the biosurfactants are polymeric biosurfactants (like emulsan, alasan, liposan, and other polysaccharide protein complexes), free fatty acids, phospholipids, and neutral lipids [13]. More extended classification of the biosurfactants of microbial origin is presented in Table 1 and examples of chemical structures of selected biosurfactants are shown in Figure 1.

Table 1. Different groups of microbial biosurfactants [14-17].

\begin{tabular}{|c|c|c|}
\hline Class & Subclass & Examples of Producers \\
\hline \multirow{5}{*}{ Glycolipids } & Rhamnolipids & $\begin{array}{l}\text { Pseudomonas aeruginosa } \\
\text { Pseudomonas sp. }\end{array}$ \\
\hline & Trehalolipids & $\begin{array}{c}\text { Mycobacterium tuberculosis } \\
\text { Nocardia sp. } \\
\text { Corynebacterium sp. } \\
\text { Rhodococcus erythropolis } \\
\text { Micrococcus luteus }\end{array}$ \\
\hline & Sophorolipids & $\begin{array}{l}\text { Candida bombicola } \\
\text { Candida magnolia } \\
\text { Candida apicola } \\
\text { Candida bogoriensis } \\
\text { Torulopsis bombicola } \\
\text { Torulopsis petrophilum } \\
\text { Torulopsis apicola }\end{array}$ \\
\hline & Xylolipids & $\begin{array}{l}\text { Lactococcus lactis } \\
\text { Pichia caribbica }\end{array}$ \\
\hline & Cellobiolipid & Cryptococcus humicola \\
\hline \multirow{7}{*}{ Lipopeptides } & Surfactin & Bacillus subtilis \\
\hline & Iturin & Bacillus subtilis \\
\hline & Fengycin & Bacillus subtilis \\
\hline & Lichenysin & Bacillus licheniformis \\
\hline & Viscosinamid & P. fluorescens \\
\hline & Viscosin & P. libanensis \\
\hline & Flavolipid & Flavobacterium sp. \\
\hline Fatty Acid Biosurfactant & & $\begin{array}{c}\text { Arthobacter sp. } \\
\text { Pseudomonas aeruginosa }\end{array}$ \\
\hline \multirow{4}{*}{ Polymeric Biosurfactants } & Emulsan & Acinetobacter calcoaceticus \\
\hline & Biodispersan & Acinetobacter calcoaceticus \\
\hline & Alasan & Acinetobacter radioresistens \\
\hline & Liposan & Candida lipolytica \\
\hline
\end{tabular}




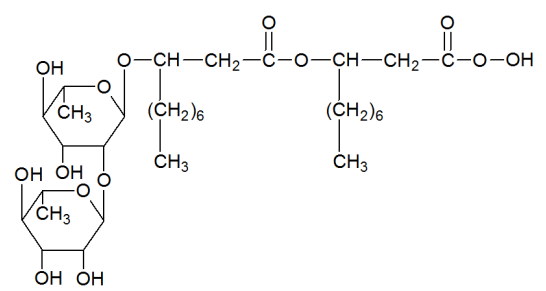

(a)

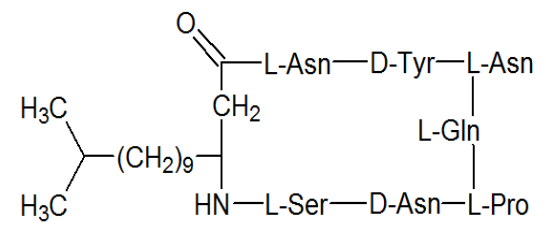

(c)

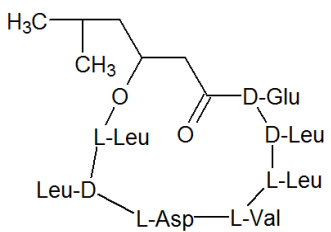

(b)

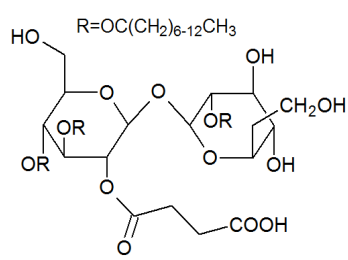

(d)

Figure 1. Structures of selected biosurfactants: (a) rhamnolipids [18], (b) surfactin [19], (c) iturin A [20], and (d) trehalose tetraester [21].

Biosurfactants can enhance hydrocarbon biodegradation by bacteria present in the environment by two main mechanisms. The first includes the increase in the substrate bioavailability for microorganisms. The second is connected with the cells modification, including changes in cells surface hydrophobicity and membrane permeability [22]. However, Franzetti et al. [23] distinguished four phenomena accompanying biosurfactant-enhanced biodegradation with a slightly different attitude: (a) emulsification, (b) micellization, (c) adhesion-deadhesion of microorganisms to and from hydrocarbons, and (d) desorption of contaminants.

Although the impact of biosurfactants on hydrocarbons bioremediation was studied before, so far very little attention has been paid to the biosurfactants influence on pollutants bioavailability to microbial cells. This comprehensive process engages physicochemical modifications of pollutants and biological alterations of microbial cells properties, so a comparison of the recently published results with these from earlier decades is much needed. Hence, in the next sections, several mechanisms of bioavailability enhancement caused by microbial surfactants will be broadly discussed.

\section{Hydrocarbon Emulsification and Desorption with Biosurfactants}

The main process taking place in aqueous environment into which biosurfactants have been introduced is the formation of emulsions as well as desorption of hydrophobic compounds (Figure 2) [24]. Biosurfactants allow the scattering of substances slightly or virtually immiscible with aqueous phase in aqueous solution $[25,26]$. These bioactive compounds reduce interfacial tension between immiscible liquids and increase the solubility of hydrocarbons [27]. As a result, the interfacial mass exchange in the surface multiplies, which translates into an increase in the permeation of organic compound molecules to the solution, increasing the availability of the biodegradable compounds to cells [22,28]. At the same time, the reduction of interfacial tension leads to increased penetration of porous materials (e.g., soil and bottom sediments) through the aqueous phase [29,30]. Surfactants in the amounts above the critical micellar concentration (CMC) can form micelles in aqueous solution. This parameter is usually used to evaluate the efficiency of surfactants. In aqueous phase, when their concentration is above CMC, surfactant micelles have a hydrophobic core, and therefore they can accumulate hydrophobic hydrocarbons. As a result the aqueous hydrocarbons' solubility is increased [31]. It was also observed that in biological systems the critical micellar concentration could be even five times higher [32]. Kaczorek et al. [33] have shown that in a biological system (with bacteria cells) the CMC of rhamnolipids was three times higher than in pure water. It should be also noticed that the formation of micelles with the surfactant and the closure of impurities in them can bring 
ambivalent results. On the one hand, an easier transport of pollutant particles to microbial cells in an aqueous solution is observed [34], which contributes to an increase in bioavailability [35,36]. It is also possible that the hydrocarbons can be taken directly by microbial cells from micelles [37]. On the other hand, long-term closure of the biodegradable substance in the micelles may occur. Then, its penetration into the cells is significantly reduced, especially when the micelles combine and their mass increases, which is associated with an increase in the sedimentation rate [38]. In addition, the surfactant adsorbs at the interface to inhibit cell access to the hydrophobic substrate [39]. Another unfavorable phenomenon is the formation of foam on the surface of the system, e.g., a water reservoir in which biodegradation takes place. Its presence can significantly reduce gas exchange between the water phase and the surrounding air. Therefore, the amount of oxygen entering the solution and the carbon monoxide (IV) released are reduced $[40,41]$.

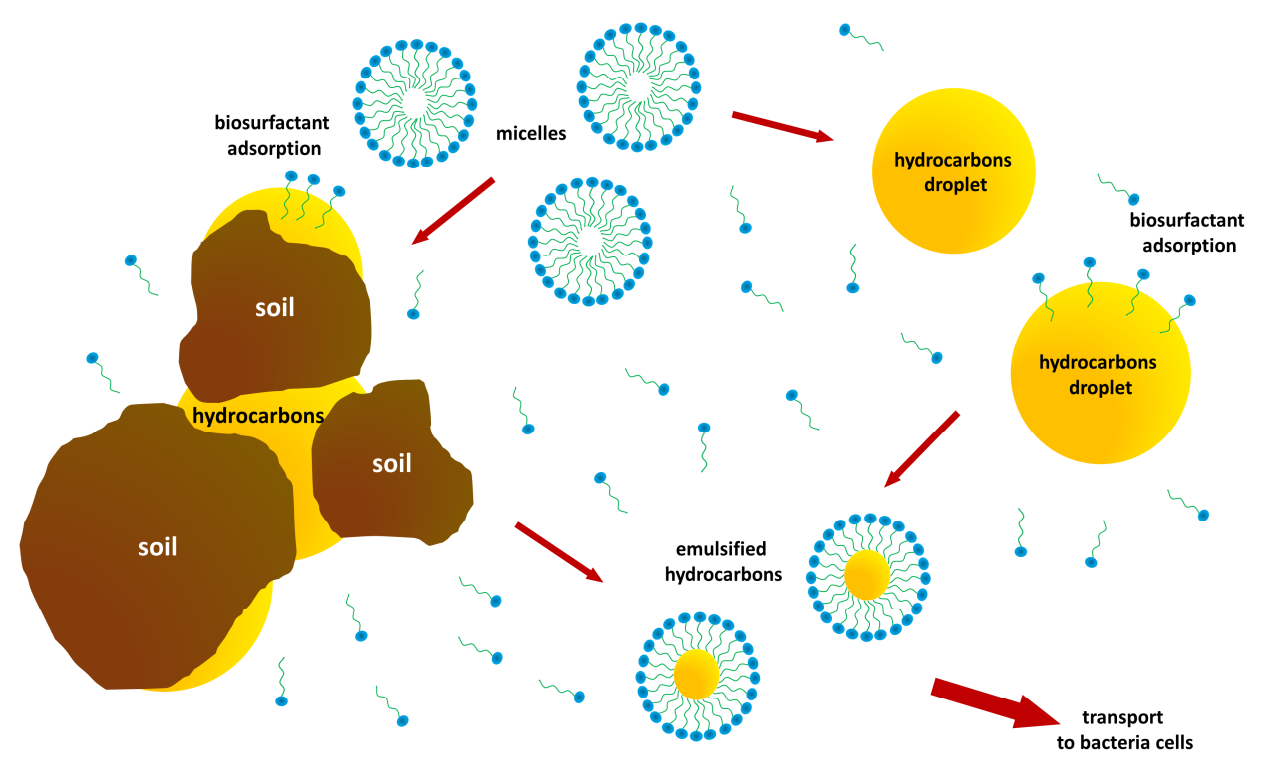

Figure 2. Main mechanisms of hydrocarbons desorption and emulsification enhanced with biosurfactants.

An important factor describing the possibility of surfactants to create stable emulsions is the emulsification index [42]. Suganthi et al. [43] have observed that the lipoprotein biosurfactants emulsify petrol and diesel oil with emulsification index ranging from 56 to $78 \%$. High emulsification index values in systems with various hydrocarbons, which are potential pollutants, have been reported by many authors, like Jamil et al., Ma et al., Peele et al., and Costa et al. [44-47]. Lee et al. [48] have directly suggested that the production of biosurfactants increases the emulsification of crude oil which is followed by higher biodegradation, thus allowing more effective degradation of the crude oil hydrocarbons by the bacterial strains [48]. Mohanty and Mukherji [49] studied the impact of biosurfactants (JBR-515 rhamnolipids) and Triton X-100 on biodegradation of six petroleum hydrocarbons (naphthalene, 1-methylnaphthalene, hexadecane, octadecane, nonadecane, and pyrene) by the Burkholderia multivorans (NG1) strain. Although both surfactants increased the biodegradation of the pollutants, different mechanisms were involved. Triton X-100 noticeably emulsified the hydrocarbons as well as modified the bacteria cells surface. On the contrary, the biosurfactant did not emulsify the hydrocarbons mixture. Moreover, the changes occurring on the bacteria cell surface suggested that it would not consistently favor direct uptake of the hydrocarbons. Hence, the authors concluded that the enhancement of biodegradation may be caused by micellar solubilization of the hydrophobic carbon source [49].

The activity of biosurfactants is also accompanied by the enhanced detachment of pollutant particles from the matrix and their dispersion in the solution [35]. Increased desorption of pollutants from solid surfaces is important especially during the bioremediation of soils $[34,36]$. Biosurfactants, 
like rhamnolipids, can improve desorption of polycyclic aromatic hydrocarbons (PAHs) [22,50], even in the case of aged pollutants [51,52]. Congiu and Ortega-Calvo [51] have indicated that the increased desorption enhanced by rhamnolipids from P. aeruginosa 19SJ results in phenanthrene and pyrene mineralization. The researchers noticed that thanks to rhamnolipids the risk associated with increased concentrations of solubilized PAHs and their toxic metabolites can be minimized. Wide discussion of desorption kinetics of PAHs improved by the lipopeptide produced by a P. aeruginosa strain has also been presented by Bezza and Nkhalambayausi-Chirwa [53]. In contrast, Yao et al. have observed that the introduction of rhamnolipid in the soil during the aging process led to an increase in desorption efficiency of phenanthrene [54]. They concluded that the biosurfactants supplementation would effectively minimize the sequestration of pollutants and it is favorable for the remediation processes. What is more, the increased desorption in the presence of biosurfactants was followed by increased bioavailability of micronutrients, which also has important effect on biodegradation efficiency [24]. However, increased desorption does not always result in increased bioremediation effectiveness. Crampon et al. [55] have observed that the amendment of rhamnolipids changed the phenanthrene sorption and desorption isotherms in the two soils tested, but simultaneously there was no noticeable influence of biosurfactant on hydrocarbon degradation. What is important, is that the soil or sediments are complex systems and the presence of other compounds (apart of biosurfactants) can strongly change the effectiveness of biosurfactants surface activity [56].

The above mentioned mechanisms of biosurfactants interactions with pollutant molecules play a key role in the enhancement of hydrocarbons bioavailability to the cells. Effectiveness of biosurfactants in these processes is comparable to that of the synthetic ones, although biological molecules are milder in their activity, which makes them a better choice for environmental applications with respect to the indigenous ecosystem.

\section{Biosurfactant-Bacteria Interactions}

The use of biosurfactants in supporting the biodegradation of hydrophobic hydrocarbon pollutants raises the question about the impact of these natural surfactants on the cells of microorganisms involved in bioremediation (Figure 3). The issue has become the focus of interest for many researchers, also in recent years, hence the need to summarize research devoted to this issue.

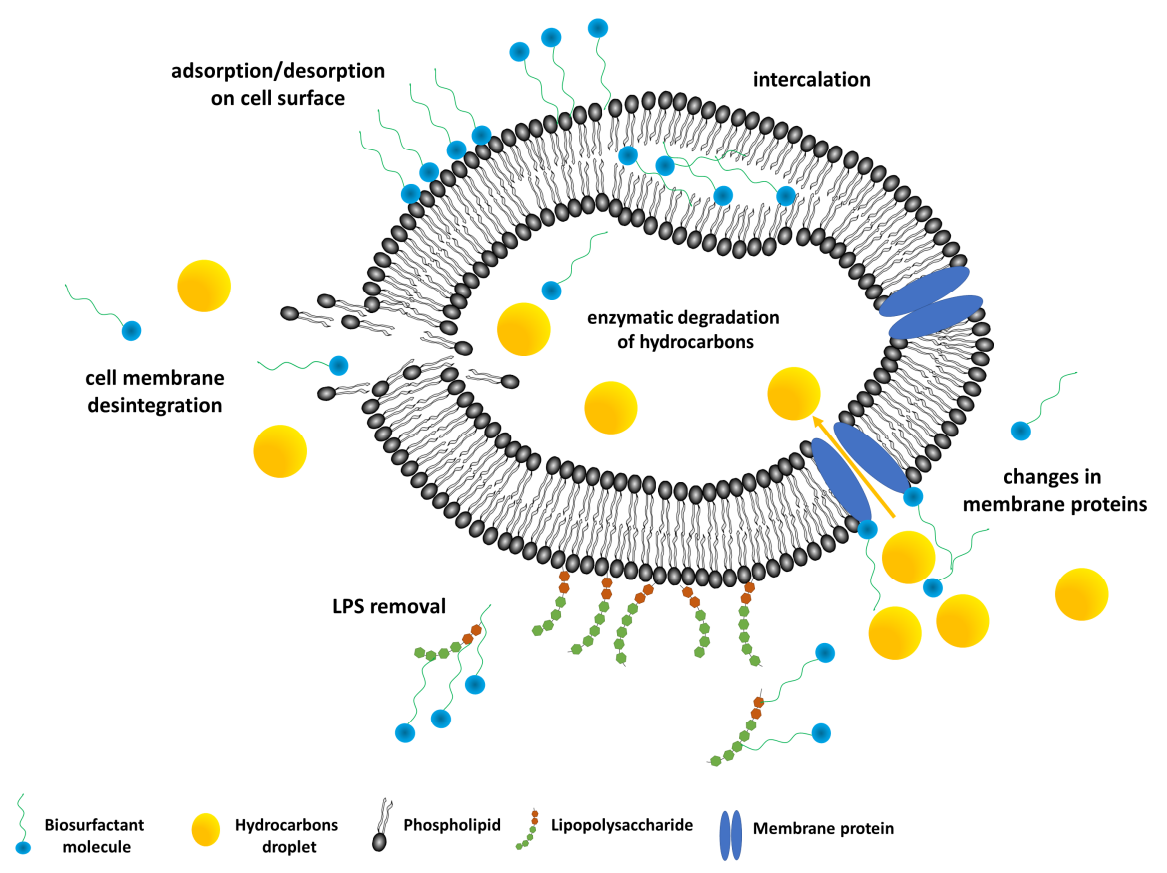

Figure 3. Main interactions between bacteria cells and biosurfactants molecules. 


\subsection{Impact on Microbial Cell Surface Properties}

While discussing the processes occurring in the ecosystem (at the microbiological level) under the influence of surfactants, attention should be paid to the modification of the microbial cell surface. Contact with surface-active compounds may result in changes in cell wall structure or the nature of extracellular substances released. The effect on the cell characteristics is also conditioned by the type of carbon source being absorbed and by environmental factors such as temperature and $\mathrm{pH}$ [57]. Modifications of cell surface properties can be quantified, e.g., by microbial adhesion to hydrocarbons (MATH) or zeta potential.

It was shown by many studies that biosurfactants influence cells surface properties, causing some significant alterations of cell surface hydrophobicity, electrokinetic potential, biomorphology, and surface functional groups $[9,58]$. As mentioned above, biosurfactants are able to modify cell surface properties thus promoting their adhesion to pollutants or enhance their partitioning and bioavailability to microorganisms. Table 2 summarizes the analyzed microbial cells properties after treatment with various biosurfactants at different concentrations.

Cells surface hydrophobicity (CSH) is one of the most often analyzed parameters, due to relatively simple measurement procedure. Microbial adhesion to hydrocarbons describes the tendency of cells to adhere to a hydrophobic interface, e.g., emulsion droplets [59]. There are a few ways to analyze cell surface hydrophobicity, among which the most commonly used is microbial/bacterial adherence to hydrocarbons (MATH/BATH) method, described by Rosenberg et al. [60]. By increasing the hydrophobicity of microbial cell surface, which occurs through remodeling of the outer layers of the cell, microorganisms can adsorb on the surface of organic pollutants. Also, biodegradable contaminants have then a greater tendency to adhere to the cell wall [61]. It is assumed that cells with hydrophobicity values from 0 to $30 \%$ are hydrophilic and above $30 \%$ are becoming more hydrophobic, with CSH over $60 \%$ considered as hydrophobic properties [62]. Another technique to evaluate CSH is contact angle measurement for microorganisms deposited on membrane filters, using different diagnostic liquids, such as water, formamide and diiodomethane $[63,64]$. Many studies have shown that biosurfactants, mainly rhamnolipids, cause a decrease in cell surface hydrophobicity for primary hydrophobic cells [49,65-68] Similarly, a drop in CSH was noticed for high concentrations of biosurfactants (above $60 \mathrm{mg} \mathrm{L}^{-1}$ ) [49,50] or when rhamnolipids were used in bacterial consortia [69]. This phenomenon might be correlated to two possible mechanisms of biosurfactant-microbial cell interactions: (a) surfactants can absorb on cells surface with their hydrophilic part exposed outward thus decreasing CSH [66]; (b) alterations of the cell surface functional groups may occur, as well as removal of extracellular hydrophobic substances from the cell surface by rhamnolipids [68]. On the other hand, it was demonstrated that an increase in Paenibacillus sp. PRNK-6 cell surface hydrophobicity to the same extent as Tween-80 and Tween-40 [70] which might be contributed to lipopolysaccharides loss from the membrane, as reported by Al-Tahhan et al. [71].

Such biomorphology modifications have been confirmed by scanning electron microscopy of the cells. Lin et al. [66] observed the loss of filamentary materials and changes in the Sphingomonas sp. GY2B cells structure with higher rhamnolipid doses by scanning electron microscopy, similarly, Rhodococcus sp. D-1 cells deformations with increasing biosurfactant concentration were observed by Bai et al. [72]. Sotirova et al. recorded some cavitation of B. subtilis 168 [73] and Pseudomonas aeruginosa NBIMCC 1390 [74] cell membrane, whereas Ma et al. [50] noted deformations of the Pseudomonas sp. Ph6 cells and the loss of exopolysaccharides from the outer membrane, in the presence of rhamnolipids concentration exceeding $100 \mathrm{mg} \mathrm{L}^{-1}$. The observed modifications of cell biomorphology might result from the different physiological status of biosurfactant treated cells, as well as proteins and polymeric substances removal from the cell surface. 
Table 2. Cell surface parameters affected by biosurfactants addition and effects of this treatment.

\begin{tabular}{|c|c|c|c|c|c|c|c|c|}
\hline & Biosurfactant & Biourfactant Source & $\begin{array}{c}\text { Surfactant } \\
\text { Concentration }\end{array}$ & Affected Microorganisms & Effect & Method & Additional Factors & Reference \\
\hline \multirow{9}{*}{ 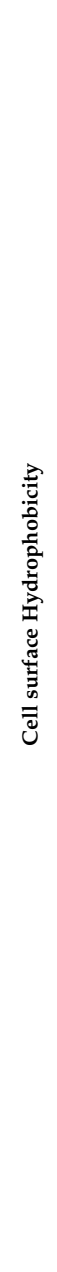 } & Rhamnolipid & $\mathrm{N} / \mathrm{D}$ & $0-8 \mathrm{CMC}$ & Klebsiella oxytoca & $\begin{array}{l}\text { - Increase of CSH for hydrophilic consortia; } \\
\text { - Reduction of CSH for hydrophobic consortia }\end{array}$ & BATH & - & [65] \\
\hline & Biosurfactant & Joostella sp. A8 & N/D & $\begin{array}{l}\text { Joostella sp. A8 } \\
\text { Pseudomonas A6 } \\
\text { Joostella sp. A8 } \\
\text { Alcanivorax } \mathrm{A} 53 \text { consortium }\end{array}$ & $\begin{array}{l}\text { Primal increase in J-P consortium CSH values } \\
\text { for the first } 8 \mathrm{~h} \text {, than collapse to } 4 \% \text {; } \\
\text { Initial small increase in J-A consortium CHS } \\
\text { values, than decline to approx. } 15 \% \text {. }\end{array}$ & BATH & $\begin{array}{l}\text { cultures supplemented } \\
\text { with diesel oil }\end{array}$ & [69] \\
\hline & $\begin{array}{l}\text { Rhamnolipids } \\
\text { (Purity } \geq 98 \% \text { ) }\end{array}$ & $\begin{array}{l}\text { Huzhou Zijin } \\
\text { Biological Technology } \\
\text { Company }\end{array}$ & $0 ; 0.2 ; 1$ and $4 \mathrm{CMC}$ & Sphingomonas sp. GY2B & $\begin{array}{l}\text { - Addition of rhamnolipids generally decreased } \\
\text { the CSH of the primary hydrophobic cells after } \\
24 \text { and } 48 \mathrm{~h}\end{array}$ & MATH & $\begin{array}{l}\text { cells analyzed after } 24 \mathrm{~h} \\
\text { phenanthrene } \\
\text { degradation }\end{array}$ & [66] \\
\hline & Rhamnolipid & $\begin{array}{l}\text { Pseudoxanthomo-nas } \\
\quad \text { sp. PNK-04 }\end{array}$ & $25 \mathrm{mg} / \mathrm{L}$ & Paenibacillus sp. PRNK-6 & $\begin{array}{l}\text { - Rhamnolipid increased CHS to the same extend } \\
\text { as Tween-80 and Tween-40 }\end{array}$ & BATH & - & [70] \\
\hline & Biosurfactant BS-UC & Candida antarctica & $0-3 \%$ & Candida antarctica & $\begin{array}{l}\text { - Increase in cells adhesion to kerosene with the } \\
\text { concentration of BS-UC } \\
\text { Maximum CHS when the concentration of } \\
\text { BS-UC was above } 2 \%\end{array}$ & MATH & $\begin{array}{l}\text { cells cultured with } 8 \% \\
(v / v) \text { of undecane, } \\
\text { hexadecane, soybean oil, } \\
\text { or glucose }\end{array}$ & [75] \\
\hline & Rhamnolipid (90\%) & AGAE Technologies & $\begin{array}{l}0 ; 5 ; \\
50 ; 100 ; 200 \text { and } \\
400 \mathrm{mg} \mathrm{L}^{-1}\end{array}$ & Pseudomonas sp. Ph6 & $\begin{array}{l}\text { Rhamnolipid in concentration from } 0 \text { to } 100 \mathrm{mg} \\
\mathrm{L}^{-1} \text { increased CSH, while higher concentrations } \\
\text { (up to } 400 \mathrm{mg} \mathrm{L}^{-1} \text { ) reduced cells hydrophobicity }\end{array}$ & MATH & $\begin{array}{l}\text { cells cultured with } \\
\text { phenanthrene addition } \\
\left(50 \mathrm{mg} \mathrm{L}^{-1}\right)\end{array}$ & [50] \\
\hline & Rhamnolipid & $\begin{array}{l}\text { Jeneil Biosurfactant } \\
\text { Company, USA }\end{array}$ & $2 \mathrm{CMC}$ & Burkholderia multivorans & $\begin{array}{l}\text { - Cells hydrophobicity decreased from } \\
\text { hydrophobic to hydrophilic range }\end{array}$ & $\begin{array}{l}\text { water contact } \\
\text { angle }\end{array}$ & $\begin{array}{l}\text { addition of } 0.1 \%(v / v) \\
\quad \text { NAPL }\end{array}$ & [49] \\
\hline & $\begin{array}{l}\text { Rhamnolipids } \\
\text { JBR } 425\end{array}$ & $\begin{array}{l}\text { Jeneil Biosurfactant } \\
\text { Company, USA }\end{array}$ & $\begin{array}{l}\text { 6; 30; 60; 120; } 150 ; 240 ; \\
\quad 360 \mathrm{mg} \mathrm{L}^{-1}\end{array}$ & $\begin{array}{l}\text { Pseudomonas fluorescens (P1) } \\
\text { Pseudomonas putida } \mathrm{K} 1\end{array}$ & $\begin{array}{l}\text { P. putida }(\mathrm{K} 1) \text { strains have hydrophilic } \\
\text { properties in systems with surfactants as the } \\
\text { only carbon source; hydrophobicity increased } \\
\text { when hydrocarbons were added to the system; } \\
\text { use of higher than } 60 \mathrm{ml} \mathrm{L}^{-1} \text { doses of } \\
\text { surfactants caused a decrease in hydrophobicity } \\
\text { Reverse situation was in system with P1, } \\
\text { primary hydrophobic bacteria became } \\
\text { hydrophilic with surfactant concentration } \\
\text { exceeding } 60 \mathrm{mg} \mathrm{L}^{-1}\end{array}$ & MATH & $\begin{array}{l}\text { different carbon sources } \\
\text { with surfactants or } \\
\text { surfactants only }\end{array}$ & [67] \\
\hline & Rhamnolipids & $\begin{array}{l}\text { P. aeruginosa } \\
\text { ATCC9027 }\end{array}$ & $\begin{array}{l}\text { 0, } 20,40,120 \\
\text { and } 400 \mathrm{mg} \mathrm{L}^{-1}\end{array}$ & $\begin{array}{l}\text { B. subtilis BUM } \\
\text { P. aeruginosa } \\
\text { P-CG3 }\end{array}$ & $\begin{array}{l}\text { - Rhamnolipids significantly reduced the CSH of } \\
\text { B. subtilis BUM and increased the CSH of } P \text {. } \\
\text { aeruginosa P-CG3 } \\
\text { In case of mixed cultures the CSH values with } \\
\text { rhamnolipids were very close to the average } \\
\text { values for the two strains }\end{array}$ & $\begin{array}{l}\text { nitrocellulose } \\
\text { filter test }\end{array}$ & $\begin{array}{l}\text { single or mixed bacterial } \\
\text { strains before } \\
\text { and after } \\
\text { PAH degradation }\end{array}$ & [68] \\
\hline
\end{tabular}


Table 2. Cont.

\begin{tabular}{|c|c|c|c|c|c|c|c|c|}
\hline & Biosurfactant & Biourfactant Source & $\begin{array}{c}\text { Surfactant } \\
\text { Concentration }\end{array}$ & Affected Microorganisms & Effect & Method & Additional Factors & Reference \\
\hline & $\begin{array}{l}\text { Rhamnolipid- } \\
\text { Biosurfactant PS }\end{array}$ & Pseudomonas sp. PS-17 & $50 ; 300 \mu \mathrm{g} \mathrm{mL}^{-1}$ & $\begin{array}{l}\text { Pseudomonas aeruginosa } \\
\quad \text { NBIMCC } 1390\end{array}$ & $\begin{array}{l}\text { - Slight increase in CSH of primary hydrophilic } \\
\text { cells after surfactant addition }\end{array}$ & BATH & - & [74] \\
\hline & $\begin{array}{l}\text { Rhamnolipids RL } \\
\text { (90\% Purity) }\end{array}$ & $\begin{array}{c}\text { Gemking } \\
\text { Biotechnology Ltd. } \\
\text { (Huzhou, China) }\end{array}$ & $0 ; 50 ; 150 \mathrm{ppm}$ & Rhodococcus sp. D-1 & - $\quad$ RL increased CSH & $\begin{array}{c}\text { BATH and } \\
\text { water contact } \\
\text { angle } \\
\end{array}$ & $\begin{array}{l}\text { Cells cultured with } \\
200 \mathrm{ppm} \text { of Carbendazim }\end{array}$ & [72] \\
\hline \multirow{5}{*}{ 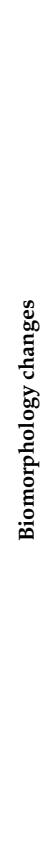 } & $\begin{array}{c}\text { Rhamnolipid- } \\
\text { Biosurfactant PS }\end{array}$ & Pseudomonas sp. PS-17 & $50 ; 300 \mu \mathrm{g} \mathrm{mL}^{-1}$ & $\begin{array}{l}\text { Pseudomonas aeruginosa } \\
\text { NBIMCC } 1390\end{array}$ & $\begin{array}{l}\text { Below CMC the cell surface structures became } \\
\text { smooth, thin and indistinct } \\
\text { Above CMC membrane was disrupted and } \\
\text { became translucent, but it did not affect } \\
\text { cells viability }\end{array}$ & TEM & - & [74] \\
\hline & $\begin{array}{c}\text { Rhamnolipid- } \\
\text { Biosurfactant PS } \\
\text { (Rhamnolipid + } \\
\text { Alginate) } \\
\end{array}$ & Pseudomonas sp. PS-17 & $0.5 \%$ & Bacillus subtilis 168 & $\begin{array}{l}\text { - Modified cell shapes and folded cell membranes, } \\
\text { with different cavities, obscured cells }\end{array}$ & SEM & - & [73] \\
\hline & $\begin{array}{l}\text { Rhamnolipids RL } \\
\text { (90\% Purity) }\end{array}$ & $\begin{array}{l}\text { Gemking } \\
\text { Biotechnology Ltd. } \\
\text { (Huzhou, China) }\end{array}$ & $0 ; 50 ; 150 \mathrm{ppm}$ & Rhodococcus sp. D-1 & $\begin{array}{l}\text { - Reduction of cells length and width with } \\
\text { RL addition } \\
\text { More profound deformations with rhamnolipid } \\
\text { concentration increase }\end{array}$ & SEM & $\begin{array}{c}\text { cells cultured with } \\
200 \mathrm{ppm} \text { of Carbendazim }\end{array}$ & [72] \\
\hline & Rhamnolipid (90\%) & AGAE Technologies & $\begin{array}{c}\text { 0; 5; } \\
50 ; 100 ; 200 \text { and } \\
400 \mathrm{mg} \mathrm{L}^{-1}\end{array}$ & Pseudomonas sp. Ph6 & $\begin{array}{l}\text { - An increase in the extracellular polymeric } \\
\text { substance (EPS) thickness on Ph6 cells (with } \\
\text { rhamnolipids concentration } 0-100 \mathrm{mg} \mathrm{L}^{-1} \text { ) and } \\
\text { loss when concentration exceed } 200 \mathrm{mg} \mathrm{L}^{-1} \\
\text { Higher concentrations deformated cells, with } \\
\text { part of the cytochylema boundary separated } \\
\text { from the cell envelope }\end{array}$ & TEM & $\begin{array}{l}\text { cells cultured with } \\
\text { phenanthrene addition } \\
\left(50.0 \mathrm{mg} \mathrm{L}^{-1}\right)\end{array}$ & [50] \\
\hline & $\begin{array}{l}\text { Rhamnolipids } \\
\text { (Purity } \geq 98 \% \text { ) }\end{array}$ & $\begin{array}{l}\text { Huzhou Zijin } \\
\text { Biological Technology } \\
\text { Company }\end{array}$ & $0,0.2 ; 1$ and $4 \mathrm{CMC}$ & Sphingomonas sp. GY2B & $\begin{array}{l}\text { - Mellow and full structure of the cells, } \\
\text { maintained with increasing } \\
\text { rhamnolipid concentration } \\
\text { - Filamentary materials appeared with } 0 \text { or } 0.2 \\
\text { CMC rhamnolipids at } 24 \mathrm{~h} \text {, whereas they } \\
\text { decreased or disappeared with higher doses } \\
\text { of rhamnolipids }\end{array}$ & SEM & $\begin{array}{l}\text { cells analyzed after } 24 \\
\text { and } 48 \mathrm{~h} \text { phenanthrene } \\
\text { degradation }\end{array}$ & [66] \\
\hline \multirow{2}{*}{ 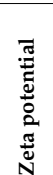 } & $\begin{array}{l}\text { Rhamnolipids } \\
\text { (Purity } \geq 98 \% \text { ) }\end{array}$ & $\begin{array}{c}\text { Huzhou Zijin } \\
\text { Biological Technology } \\
\text { Company }\end{array}$ & $0 ; 0.2 ; 1$ and $4 \mathrm{CMC}$ & Sphingomonas sp. GY2B & $\begin{array}{l}\text { - Addition of biosurfactant increased the positive } \\
\text { electric charge of the cell surface }\end{array}$ & $\begin{array}{l}\text { laser Doppler } \\
\text { velocimetry }\end{array}$ & $\begin{array}{l}\text { cells analyzed after } 24 \mathrm{~h} \\
\text { phenanthrene } \\
\text { degradation }\end{array}$ & [66] \\
\hline & $\begin{array}{l}\text { Biosurfactants } \\
\text { BS-UC and MEL }\end{array}$ & C. antarctica & $0 ; 1 \% ; 2 \%$ and $3 \%$ & C. antarctica & $\begin{array}{l}\text { - Addition of biosurfactant increased the positive } \\
\text { electric charge of the cell surface }\end{array}$ & $\begin{array}{l}\text { dynamic light } \\
\text { scattering }\end{array}$ & - & [75] \\
\hline
\end{tabular}


Table 2. Cont

\begin{tabular}{|c|c|c|c|c|c|c|c|c|}
\hline & Biosurfactant & Biourfactant Source & $\begin{array}{c}\text { Surfactant } \\
\text { Concentration }\end{array}$ & Affected Microorganisms & Effect & Method & Additional Factors & Reference \\
\hline & Rhamnolipid (90\%) & AGAE Technologies & $\begin{array}{l}0 ; 5 ; \\
50 ; 100 ; 20 \text { and } \\
400 \mathrm{mg} \mathrm{L}^{-1}\end{array}$ & Pseudomonas sp. Ph6 & $\begin{array}{l}\text { - Increasing proton acceptability of the membrane } \\
\text { with rhamnolipid concentration from } 0 \text { to } \\
100 \mathrm{mg} \mathrm{L}^{-1} \\
\text { - Zeta potential dropped when concentrations } \\
\text { enhanced from } 100 \text { to } 400 \mathrm{mg} \mathrm{L}^{-1}\end{array}$ & $\begin{array}{l}\text { Zetaphore-meter } \\
\text { (Les Essarts-le- } \\
\text { Roi, France) }\end{array}$ & $\begin{array}{l}\text { cells cultured with } \\
\text { phenanthrene addition } \\
\left(50 \mathrm{mg} \mathrm{L}^{-1}\right)\end{array}$ & [50] \\
\hline & $\begin{array}{l}\text { Rhamnolipid } \\
\text { JBR } 515\end{array}$ & $\begin{array}{l}\text { Jeneil Biosurfactant } \\
\text { Company, USA }\end{array}$ & $2 \mathrm{CMC}$ & Burkholderia multivorans & $\begin{array}{l}\text { - JBR-515 increased the electronegativity of } \\
\text { the cells }\end{array}$ & $\begin{array}{l}\text { Zeta potential } \\
\text { analyzer (Zeta } \\
\text { Pals) } \\
\end{array}$ & $\begin{array}{l}\text { Addition of } 0.1 \%(v / v) \\
\quad \text { NAPL }\end{array}$ & [49] \\
\hline & $\begin{array}{l}\text { Rhamnolipids RL } \\
\text { (90\% Purity) }\end{array}$ & $\begin{array}{l}\text { Gemking } \\
\text { Biotechnology Ltd. } \\
\text { (Huzhou, China) }\end{array}$ & $0 ; 50 ; 150 \mathrm{ppm}$ & Rhodococcus sp. D-1 & $\begin{array}{l}\text { - Electronegativity of the cells was lowered with } \\
\text { increasing concentration of RL }\end{array}$ & $\begin{array}{l}\text { ZetaSizer } \\
\text { Nano-ZS } \\
\text { Zen } 3600\end{array}$ & $\begin{array}{l}\text { Cells cultured with } \\
200 \mathrm{ppm} \text { of Carbendazim }\end{array}$ & [72] \\
\hline \multirow{4}{*}{ 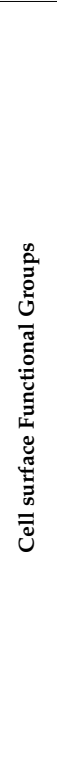 } & $\begin{array}{l}\text { Rhamnolipids } \\
\text { (Purity } \geq 98 \% \text { ) }\end{array}$ & $\begin{array}{l}\text { Huzhou Zijin } \\
\text { Biological Technology } \\
\text { Company }\end{array}$ & $0 ; 0.2$ and $1 \mathrm{CMC}$ & Sphingomonas sp. GY2B & $\begin{array}{l}\text { - Addition of rhamnolipids caused the change of } \\
\text { these transmittance peaks and affected the } \\
\text { degradation efficiency }\end{array}$ & FTIR & $\begin{array}{l}\text { freeze dried cells } \\
\text { analyzed after } 24 \mathrm{~h} \\
\text { phenanthrene } \\
\text { degradation } \\
\end{array}$ & [66] \\
\hline & Rhamnolipid (90\%) & AGAE Technologies & $\begin{array}{l}0 ; 5 ; \\
50 ; 100 ; 200 \text { and } \\
400 \mathrm{mg} \mathrm{L}^{-1}\end{array}$ & Pseudomonas sp. Ph6 & $\begin{array}{l}\text { - Lack of lipopolysaccharides peaks }\left(990 \mathrm{~cm}^{-1}\right) \\
\text { with rhamnolipid } 0-100 \mathrm{mg} \mathrm{L}^{-1} \text { and observed } \\
\text { again for treatments with } 200 \text { or } \\
400 \mathrm{mg} \mathrm{L}^{-1} \text { rhamnolipid }\end{array}$ & FTIR & $\begin{array}{l}\text { cells cultured with } \\
\text { phenanthrene addition } \\
\left(50 \mathrm{mg} \mathrm{L}^{-1}\right)\end{array}$ & [50] \\
\hline & $\begin{array}{l}\text { Rhamnolipidsrl } \\
\text { (90\% Purity) }\end{array}$ & $\begin{array}{l}\text { Gemking } \\
\text { Biotechnology Ltd. } \\
\text { (Huzhou, China) }\end{array}$ & $0 ; 50 ; 150 \mathrm{ppm}$ & Rhodococcus sp. D-1 & $\begin{array}{l}\text { - Cells cultured with RL50 and RL150 showed } \\
\text { sharper peaks correlated to intermolecular } \\
\text { hydrogen bonded O-H }\left(3300 \mathrm{~cm}^{-1}\right) \text { and } \\
\text { bending vibrations of saturated alcohol } \\
\left(1398 \mathrm{~cm}^{-1}\right) \text { and weaker valley at } 1240 \mathrm{~cm}^{-1} \text {, } \\
\text { than the control group }\end{array}$ & FTIR & $\begin{array}{l}\text { Cells cultured with } \\
200 \mathrm{ppm} \text { of Carbendazim }\end{array}$ & [72] \\
\hline & $\begin{array}{l}\text { Rhamnolipid } \\
\text { JBR } 515\end{array}$ & $\begin{array}{l}\text { Jeneil Biosurfactant } \\
\text { Company, USA }\end{array}$ & $2 \mathrm{CMC}$ & Burkholderia multivorans & 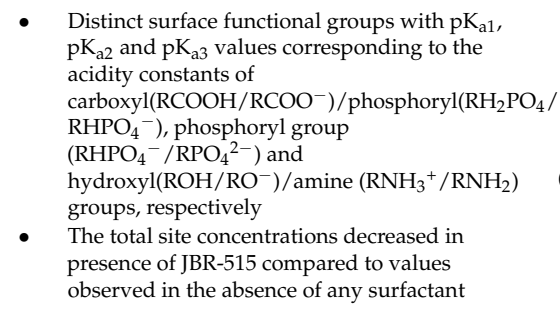 & $\begin{array}{c}\text { surface } \\
\text { complexation } \\
\text { modeling } \\
\text { (potentiometric } \\
\text { titration) }\end{array}$ & $\begin{array}{l}\text { Addition of } 0.1 \%(v / v) \\
\text { NAPL }\end{array}$ & [49] \\
\hline
\end{tabular}

N/D—no data; RL—rhamnolipids; CMC—critical micelle concentration; $\mathrm{CSH}-$ cell surface hydrophobicity. 
Biosurfactants are known also for their impact on cell electrokinetic (zeta) potential [9]. The zeta potential describes the tendency of solid particles or droplets of emulsions present in the colloidal system for sedimentation and aggregation. The higher the absolute value of the zeta potential, the more stable the system, e.g., the suspension of bacterial cells [76]. The value of the zeta potential is a result of interactions between functional groups of the outer layers of the cell and substances present in the surrounding environment [77]. The stability of the system in which biodegradation takes place is crucial for maintaining a high rate of mass exchange between cells, solution, and biodegraded compound. Changes in cell surface properties may indicate an increase or decrease in the affinity of cells to biodegradable compounds in the presence of surfactants [78]. The cells zeta potential is usually measured using automatic zeta potential meters, based on dynamic light scattering and Henry's equation, however, laser Doppler velocimetry might be also employed to determine the value of this parameter. The authors studying this property reported that adsorption of biosurfactants on the cell surface mostly increase the positive electric charge of the microbial cell surface [50,66,73]. However, Mohanty and Mukherji [49] have found that rhamnolipid JBR 515 added in a concentration of 2 CMC increased the electronegativity of Burkholderia multivorans. Soni et al. [79] on the basis of electrokinetic potential measurements of cells in various nutrient and physiological conditions, suggested that bacterial size and zeta potential are connected with the microbes' physiological state. It should be also noticed that more often observed decrease in cells electronegativity is interpreted as promoting cells adhesion to pollutants [49].

Finally, the interactions of the cells with the environment depend also upon carboxyl, phosphate, and amino functional groups present on the cell surface. Their presence can be confirmed with the use of Fourier transform infrared spectroscopy (FTIR). Many researchers have reported that rhamnolipids modify cell surface functional groups $[49,50,66,72]$, however the impact of different biosurfactants on various microorganisms is diverse. Changes in the cell surface lipopolysaccharides [50], saturated alcohols, intramolecular hydrogen [72], carboxyl, phosphoryl, and amine groups have been observed [49]. Such changes in cell surface characteristics seem to be correlated more with cell adhesion to pollutants, rather than with enhancement of pollutants partitioning [72].

So-far the reported findings indicate that biosurfactants have significant impact on cell surface properties, affecting various cells parameters responsible for microorganisms' adhesion to hydrophobic pollutants. In our opinion, although the mechanisms of biosurfactant-microbial cells interactions is difficult to describe due to the variety of surfactants types and cells properties, general favorable effect of biosurfactants on microbial cells, increasing pollutants bioavailability, is undeniable.

\subsection{Impact on Microbial Cell Membranes}

Apart from the strong impact on cell surface properties, surfactants influence greatly the cellular phospholipid membrane. Changes in cell membrane permeability in the presence of surfactants are associated with the penetration of surfactant molecules [80]. This process may contribute to the uncontrolled release of small metabolites, ions, or gas molecules from the cell and also applies to molecules of biodegradable substances [65]. The interaction of surfactants with the cell membrane is also one of the factors determining the toxic effect of surface-active compounds on microorganisms [81]. With the increase in membrane permeability, small molecules can penetrate into the cell, disturbing its metabolism. On the other hand, enzymes or supplementary substances may escape from the cell via a liquefied membrane [80]. The toxicity of surfactants and their adverse impact on the environment is the main factor limiting their use in environmental treatment technologies [82]. Surfactants exhibit significant biological activity; they can be combined with molecules such as deoxyribonucleic acid or enzymes, changing their properties and preventing them from performing their function in cells [83]. Many of the commonly used surfactants are relatively difficult to biodegrade, and the methods used to treat contaminated soil and waters are often not effective. As a result, they accumulate in the environment, posing a threat to the autochthonous macro- and microorganisms [84]. 
The bacterial cell membrane is a sensitive lipid semipermeable bilayer. One of its main functions is to act as a barrier between the microbial cell and the environment. Generally, it consists of proteins, lipids, and polysaccharide $[85,86]$. The two major attributes of the cell membrane are permeability and fluidity; both can be affected by biosurfactants. However, it should be remembered that they change with the concentration of biosurfactant as it was shown by Sotirova et al. [73]. The presence of biosurfactant PS at the concentration of $0.01 \%$ caused the increase in permeability of Bacillus subtilis 168 cells. On the other hand, when the biosurfactant was introduced to microbial culture at the concentration higher than $0.01 \%$, the cellular membrane permeability significantly decreased.

There are many methods of determining the bacterial cell membrane permeability. They include the analyses of protein release (leakage) from intracellular area after treatment with biosurfactant [75,87-91], the release of nucleic acid from bacterial cells [88], analysis of enzymatic activity [91], as well as other techniques such as crystal violet assay [87,89], the methylene blue dye exclusion assay [92], determination of fluorescence after contact with biosurfactant [93-95], or $o$-nitrophenyl- $\beta$-galactoside (ONPG) assay which is based on the release of yellow $o$-nitrophenol after its transformation by exocellular enzymes $[96,97]$. Furthermore, in numerous publications the increased cell membrane permeability has been confirmed by several imaging methods, such as SEM analysis. All of the experiments have been usually performed using microbial cells during the late exponential growth phase after treatment with surfactants. From among the above mentioned methods, analysis of the proteins released from the microbial cell upon the presence of biosurfactant has been most commonly used [75,88-91]. The test is based on determination of the amount of proteins (e.g., using the Lowry or Bradford method) released after contact with biosurfactants and comparison of the results with the control samples [75,89]. Intracellular protein release is often accompanied by the analysis of the crystal violet uptake. During the test, the microbial cells showing higher membrane permeability are more prone to uptake the dye. The methods mentioned are easy; usually they involve spectrophotometric features of the substances, and do not need advanced equipment.

There are not many studies about the permeability of bacterial membranes within the environmental applications (Table 3). Studies focusing on the antibacterial properties of biosurfactants have been carried out regularly. Sana et al. [89] performed detailed analyses of modifications of cell membrane permeability with biosurfactants on two representatives of microbial strains: Gram negative E. coli and Gram positive S. aureus. The biosurfactants tested were rhamnolipids (P. aeruginosa C2) and BS15 (Bacillus stratosphericus A15) [89]. Scientists determined the cell permeabilization with biosurfactant through measurements of the release of extracellular protein content and analysis of the modification of cell surface hydrophobicity as well as crystal violet assay. All the results were confirmed with SEM analyses. Rhamnolipids changed significantly the crystal violet (CV) uptake by microbial strains and significantly increased the protein release.

What is important, cell membrane permeability (MP) can be measured not only using living microbial cells, but also using model membrane vesicles. Such studies were performed previously $[93,95,98]$. Ortiz et al. [98] studied the effect of bacterial trehalose lipid on model phospholipid bacterial membranes. The results showed that biosurfactants increased the fluidity of the phospholipids acyl chains. Moreover, Zaragoza et al. [95] and Carrilo et al. [93] studied the effect of trehalose lipid or surfactin on model membrane vesicles using fluorescence. The increase of permeability caused by the presence of biosurfactants was noticed during both experiments.

Moreover, Vasileva-Tonkova et al. [91] studied the effects of rhamnolipids on the yeast Saccharomyces cerevisiae cells and compared them to that of the synthetic surfactant-Triton $\mathrm{X}-100$. Under the term "cell permeability" they meant the protein release and enzymatic activity. Both surfactants increased the MP but the synthetic surfactant caused greater cell damage. Moreover, Dusane et al. [92] studied the impact of rhamnolipids on cell membrane permeability of commonly found in the environment fungus strain-Yarrowia lipolytica. They measured cell membrane permeability using the manual method with methylene blue. In comparison to the synthetic surfactant—sodium dodecyl sulfate—rhamnolipids showed lesser effectiveness to increase 
cellular membrane permeability. These results have shown rhamnolipids have worse antibacterial properties, thus their medical applications are limited. On the other hand, they could be promising when it comes to environmental applications-having increased the permeability of the bacterial membrane, rhamnolipids enhance the uptake of pollutants, which in turn could be useful in bioremediation processes.

Table 3. Impact of biosurfactants on cell membranes.

\begin{tabular}{|c|c|c|c|c|c|}
\hline Type of BS & Source of BS & Microorganism Tested & Method of Analysis & $\begin{array}{l}\text { Impact of BS } \\
\text { on CMP }\end{array}$ & References \\
\hline \multirow{2}{*}{ Rhamnolipids } & \multirow{2}{*}{$\begin{array}{l}\text { Pseudomonas } \\
\text { aeruginosa } \mathrm{C} 2\end{array}$} & E. coli & REP, CV & + & \multirow{4}{*}{ [89] } \\
\hline & & S, aureus & REP, CV & + & \\
\hline \multirow{2}{*}{$\begin{array}{c}\text { Lipopeptide Type } \\
\text { BS15 }\end{array}$} & \multirow{2}{*}{$\begin{array}{c}\text { Bacillus } \\
\text { stratosphericus A15 }\end{array}$} & E. coli & REP, CV & + & \\
\hline & & S. aureus & REP, CV & + & \\
\hline Biosurfactant PS & Pseudomonas sp. S-17 & Saccharomyces cerevisiae $83-20$ & REP \& enzymatic activity & + & [91] \\
\hline Rhamnolipids & $\mathrm{N} / \mathrm{D}$ & Y. lipolytica NCIM 3589 & $\begin{array}{l}\text { The methylene blue dye } \\
\text { exclusion assay }\end{array}$ & Weak + & [92] \\
\hline $\begin{array}{c}\text { Surfactin, Iturin } \\
\text { and Fengicin } \\
\text { (Mixture) }\end{array}$ & Bacillus subtilis & Trichosporon spp. & $\begin{array}{l}\text { REP } \\
\text { NuclA }\end{array}$ & $0+$ & [88] \\
\hline \multirow[t]{2}{*}{ Biosurfactant PS } & \multirow[t]{2}{*}{ Pseudomonas sp. S-17 } & Bacillus subtilis 168 & REP & $\begin{array}{c}\text { + (up to } 0,01 \% \\
\text { of BS) } \\
\text { - (above } 0,01 \% \\
\text { of BS) }\end{array}$ & \multirow[t]{2}{*}{ [75] } \\
\hline & & $\begin{array}{c}\text { Pseudomonas aeruginosa } \\
\text { NBIMCC } 1390\end{array}$ & REP & + & \\
\hline Rhamnolipids & $\begin{array}{l}\text { Pseudomonas } \\
\text { fluorescens HW-6 }\end{array}$ & $\begin{array}{c}\text { Bacillus sp. HW-4, } \\
\text { Arthrobacter sp. HW-7 } \\
\text { Streptococcus sp. } \\
\text { HW-9 } \\
\text { Micrococcus sp. HW-11 } \\
\text { Pseudomonas sp. HW-1 } \\
\text { Pseudomonas sp. HW-10 } \\
\text { Pseudomonas sp. HW-12 } \\
\text { Escherichia sp. HW-13 }\end{array}$ & REP & + & [90] \\
\hline Rhamnolipids & $\mathrm{N} / \mathrm{D}$ & P. aeruginosa P60 & Fluorescence & + & [94] \\
\hline Rhamnolipids & P. aeruginosa OBP1 & $\begin{array}{l}\text { Klebsiella pneumoniae } \\
\text { Staphylococcus aureus }\end{array}$ & $\mathrm{REP}, \mathrm{CV}$ & + & [87] \\
\hline
\end{tabular}

Another approach to explain changes in the cell membrane permeability by biosurfactants is connected to the release of lipopolysaccharide from the outer membrane of Gram negative microbial cells. The lipopolysaccharide is built up of the three components: the lipid tail A (which is connected to the hydrophobic part of the outer membrane), the core oligosaccharide (which is present at the surface of the membrane), and the O-antigen consisting of sugar monomers. It is believed that rhamnolipids induce the release of the LPS. Not only can they contribute to the increased cell surface hydrophobicity, but it can also alter the features of cell permeability, which can have beneficial value in terms of biodegradation efficiency (see also Section 3.1) [71,99].

No less important for pollutant bioavailability and transport is cell membrane fluidity. It depends mainly on the structure of the lipid bilayer which is influenced by the fatty acids (FAs) composition. The ratio of saturated to unsaturated FAs as well as lengths of particular FAs are important parameters. It is claimed that the vital feature of the membrane that influences its fluidity is also the content of the protein [100,101]. Biosurfactants can alter microbial membranes' fluidity: (a) its stabilization through homeoviscous adaptation (which is the process of maintaining microbial cell fluidity) and (b) altering the ratio of saturated to unsaturated fatty acids. The increased presence of unsaturated fatty acids corresponds to greater fluidity of the bacterial membrane, which in turn results in better transport of hydrophobic pollutant through the microbial cell, being the limiting step in the biodegradation processes. Such modifications (decreased ratio of saturated to unsaturated fatty acids in the presence of rhamnolipids) have been observed by several authors [66,102,103]. 
Summarizing, according to the present state of knowledge, rhamnolipids are believed to increase bacterial permeability through adsorption at the outer leaflet, movement to the inner membrane, and intercalation between the phospholipid bilayer. This mechanism leads to the reorganization of membrane's structure making it smoother and thinner [104]. Moreover, some of the biosurfactants are known to permeabilize the membranes in liposome systems [105]. It should be underlined that the majority of studies concerning the impact of biosurfactants on CMP were designed to determine the antimicrobial activity of biosurfactants. Several authors claim that an increase in cell membrane permeability implies the loss of the membrane functions leading to the inhibition of microbial growth, metabolism, and death [106]. However, the changed cell membrane permeability does not have to be related to cell death and rupture [74]. Conversely, the increase in cell permeability may facilitate the leakage of cellular metabolites, which in turn may lead to the increased synthesis of these compounds [107]. Hence, the ability of biosurfactants to enhance the cell membrane permeability is the reason for their possible application in bioremediation processes since it can enhance the intracellular transport leading to the increase in biodegradation rate.

\section{Biosurfactants-Enhanced Hydrocarbons Biodegradation}

Bioremediation is an ecofriendly and cost-effective technique. Moreover, its main advantages are efficiency and safety, as well as no risk of secondary contamination of the environment. These methods, especially pollutants treatment at the site of contamination (in situ), often requires time to remove the pollution from the environment [108]. The efficiency of biodegradation process may be enhanced by the addition of surface-active compounds [109-111]. The use of surfactants allows an increase in pollutants dispersion in the water phase as well as the desorption of the contaminants from the soil matrix. In the presence of surfactant, the modifications of microbial cell surface properties are also observed, which results in increased bioavailability of insoluble organic compounds. The use of surfactants in biodegradation is associated with the complex interactions between microorganisms, surfactant, pollutant, and soil. Moreover, several reports have shown that in the use of synthetic and natural surfactants in the biodegradation process, important is not only the surfactant type, but also its concentration $[49,112]$. It should be also noted, that the addition of surfactants does not guarantee higher efficiency of biodegradation. Many researchers have demonstrated beneficial impact of surfactants addition on organic compounds biodegradation as well as their inhibitory effect [35,113-116]. The inhibition effect depends on, among others, the surfactants structure. Moreover, Tian et al. [117] have indicated that the inhibitory effect can be connected with high surfactant concentration. Thus, recently, in bioremediation much attention has been devoted to natural surfactants produced by different kinds of microorganisms due to their properties. They have many advantages over their synthetic counterparts, such as biodegradability, high environmental compatibility, strong surface activity, and lower toxicity [56,118-120]. The demonstrated in literature activity of rhamnolipids makes them exceptionally effective for techniques regarding the removal of the effects of oil spills [121]. Zeng et al. [122] showed that monorhamnolipid enhanced hexadecane biodegradation by Candida tropicalis and better efficiency of degradation can be related to the changes in cell surface. Moreover, it has been proved that these compounds may positively influence the biodegradation of alkanes [123]. In another study, Zhang et al. [124] observed increase in petroleum hydrocarbon biodegradation in soil after rhamnolipids supplementation; after 30 days a reduction of $86.97 \%$ petroleum hydrocarbon was noticed. The rhamnolipids concentration corresponded to $2 \mathrm{CMC}$. Another example of biosurfactants use in bioremediation are the studies by Whang et al. [125] on the influence of surfactin and rhamnolipids on diesel oil biodegradation. In their study they also tested the effect of $\mathrm{pH}$ and ammonium concentration on biodegradation in a system with biosurfactants. The results indicated that both biosurfactants enhanced the rate of diesel biodegradation when applied at the concentration above CMC. They suggested that emulsification of diesel by rhamnolipids or surfactin can promote diesel degradation. 
Moreover, the addition of rhamnolipid can enhance dissolution and bioavailability of persistent pollutants such as triclosan (TCS). Guo et al. [126] observed that rhamnolipids promote triclosan biodegradation in aerobic conditions. Singh et al. [127] reported that rhamnolipids can be used in the biodegradation of chlorpyrifos and can significantly improve degradation of this pesticide. What is more, this process is not accompanied by accumulation of toxic intermediates.

The positive effect of sophorolipids on crude oil biodegradation has been also showed. A large amount of sophorolipid in the fermentation process can be produced by Candida sp. [128]. These biosurfactants may also be a good alternative for petroleum-based detergents and emulsifiers. Kang et al. [129] demonstrated that the biosurfactant produced by Candida bombicola ATCC 22214 can enhance biodegradation of saturated hydrocarbons to $80 \%$, and aromatics to $72 \%$. Moreover, sophorolipid was characterized by high soil flushing efficiency and good enhancing agent for biodegradation of hexadecane, 2-methylnaphthalene, and pristine. In addition, in a recent study the biosurfactant from Candida tropicalis UCP was tested as a potential agent improving biodegradation of motor oil [130]. Biodegradation efficiency was above $70 \%$ for indigenous marine bacteria and fungi in 28 days.

It is worth mentioning that glycolipid biosurfactants (mannosylerythritol lipids) can also improve crude oil biodegradation by Pseudomonas putida strain. This surface-active agent is produced by the yeast Pseudozyma sp. NII 08165 [131]. The authors of the publication also observed inhibitory effect of this biosurfactant on tested bacterial strain at the concentration of $11.07 \mathrm{mg} \mathrm{L}^{-1}$.

In addition to rhamnolipids, lipopeptide biosurfactants have been successfully used to remediate soil contaminated with polycyclic aromatic hydrocarbons (PAHs) $[56,132,133]$. Bezza and Chirwa [52] observed that a lipopeptidal biosurfactant produced by Bacillus cereus SPL-4 can enhance bioremediation of aged PAH-contaminated soils by a microbial consortium. The PAHs degradation efficiency reached $86.5 \%$ after biosurfactant addition, while $57 \%$ in the system without biosurfactant and nutrient amendments. Some improvements of PAH degradation after $\mathrm{N}$ and $\mathrm{P}$ addition have been noted by McKew et al. [134], however, this approach does not solve the problem of bioavailability of hydrophobic compounds. It seems, therefore, that the use of surfactants in combination with the addition of nutrients may be the best solution. Moreover, lipopeptide biosurfactant produced by Pseudomonas aeruginosa strain LPB9 increased the solubility of phenanthrene, fluoranthene, and pyrene, as well as enhanced their utilization rate up to three-fold [5]. The optimum amounts of lipopeptide was turned out to be $200 \mathrm{mg} \mathrm{L}^{-1}$ and $400 \mathrm{mg} \mathrm{L}^{-1}$. The effect of rhamnolipids addition on phenanthrene (PHE) biodegradation by Sphingomonas sp. GF2B isolated from a farmland soil was investigated by Pei et al. [135]. Although unaltered strain showed high ability to degrade phenanthrene $(83.6 \%$ of mineralization), rhamnolipids addition resulted in enhancement of the biodegradation rate to $99.5 \%$.

However, the aspect of surfactant biodegradation during pollutants biodegradation supported with a surface-active compound cannot be overlooked. The surfactant added to the biodegradation system cannot become a contaminant in the environment and should be quickly biodegraded [82]. It should be noted that a given surfactant may become an attractive source of carbon for microorganisms that will use it in the first place, giving up the decomposition of difficult to access pollutants [25]. Then the surfactant will not fulfill its function as an emulsifier of hydrophobic compounds or a compound that increases their desorption from the soil. In the overall balance, this may not necessarily mean a decrease in the efficiency of the biodegradation process. Due to the added surfactant, the microorganisms can multiply, and then a larger amount of biomass will be able to biodegrade faster hardly available compounds [82].

Surfactants may have various impacts on cells parameters, and indirectly on biodegradation of hydrophobic substances. Their interactions with cells might enhance the hydrophobicity of the latter and this phenomenon could have either positive (biodegradation improvement) or negative effect as this enhancement promotes cells aggregation and sedimentation [61]. Furthermore, the complexity of natural surface-active compounds does not permit identification of a single mechanism of their action, so it is hard to define whether changes in cell surface and membrane properties are related to 
the surfactants effect as emulsifiers or surface tension reducers. Generally, natural surfactants are less likely to rupture cell membrane and, as hypothesized Nazari et al. [136], might change membrane properties locally, thus enhancing its activity and selectivity. Kowalewski et al. [137] found that a reduction in interfacial tension in an oil-water-bacteria system is an important feature in enhanced oil recovery, but it might be caused by bacteria themselves. It is worth mentioning, that the advantages of biosurfactants as environmental-friendly compounds with high surface-active properties allow also their use in soil-washing/flushing techniques, which are aimed at organic pollutants removal from contaminated soils [138], however without biodegradation processes [30,109,139-141].

Considering the above mentioned examples, the biosurfactants are a promising alternative to synthetic surfactants, however the high cost of biosurfactant production has limited their extensive use in industry as well as in environmental protection [142].

\section{Conclusions}

The above collected results of research devoted to biosurfactant-enhanced biodegradation have revealed the complex impact of the natural surface-active compounds on the bioavailability of hydrophobic pollutants. The biosurfactants are efficient emulsifiers and promote desorption and solubilization of hydrocarbons in multiphase systems, like soil. Such phenomena significantly increase the mobility and accessibility of hydrocarbons. Another important aspect of the biosurfactants interactions are modifications of bacteria cells surface properties. The bioremediation limiting factor which is the uptake and trans-membrane transport of hydrophobic substances could be effectively overcome by the application of biosurfactants. The most studied group of biosurfactants are rhamnolipids. Their impact on the cells can be described as follows. A decrease in cell surface hydrophobicity for primary hydrophobic cells; loss of polysaccharides from the outer membrane, decrease in cells electronegativity, aggregation, sedimentation promotion, and modifications of cells surface functional groups. Described biosurfactant-dependent changes in cell membrane properties promote hydrocarbon biodegradation, and as the biosurfactants show low toxicity they are safer for environmental application.

The application of biosurfactants in bioremediation processes offers many advantages, but their possible negative impact on the cells (mainly their toxicity) cannot be neglected. Besides the known toxicity of biosurfactants to the cells, the impact on cell membrane permeability should be considered, although it does not influence significantly cell viability, thus promoting hydrophobic substrates adhesion and transfer to the cells. Nevertheless, the further research, including deeper insight in observations of the biosurfactant impact on bacteria at the molecular level, will bring additional valuable information. For example, the tracking of isotope or fluorescence labeled biosurfactant molecules would allow direct analysis of the biosurfactant-cells and biosurfactant-hydrocarbons interferences. Moreover, for now, the main limiting factor of wider biosurfactants' application is their cost, thus new sources and methods allowing cost reduction are highly appreciated. The presented comprehensive review allows better selection of biosurfactant for biodegradation of a given pollutant in contaminated areas and provides insight on biosurfactants interactions with cells and hydrophobic molecules.

Funding: The research was supported by the research grant No. 03/32/DSPB/0800 from the Poznan University of Technology.

Conflicts of Interest: The authors declare no conflicts of interest.

\section{References}

1. De Almeida, D.G.; De Cássia, R.D.C.F.S.; Luna, J.M.; Rufino, R.D.; Santos, V.A.; Banat, I.M. Biosurfactants: Promising Molecules for Petroleum Biotechnology Advances. Front Microbiol. 2016, 7, 1718. [CrossRef] [PubMed] 
2. Nwankwegu, A.S.; Onwosi, C.O. Bioremediation of gasoline contaminated agricultural soil by bioaugmentation. Environ. Technol. Innov. 2017, 7, 1-11. [CrossRef]

3. Liu, R.; Jadeja, R.N.; Zhou, Q.; Liu, Z. Treatment and Remediation of Petroleum-Contaminated Soils Using Selective Ornamental Plants. Environ. Eng. Sci. 2012, 29, 494-501. [CrossRef] [PubMed]

4. Cocârţă, D.; Stoian, M.; Karademir, A. Crude Oil Contaminated Sites: Evaluation by Using Risk Assessment Approach. Sustainability 2017, 9, 1365. [CrossRef]

5. Bezza, F.A.; Nkhalambayausi Chirwa, E.M. Biosurfactant-enhanced bioremediation of aged polycyclic aromatic hydrocarbons (PAHs) in creosote contaminated soil. Chemosphere 2016, 144, 635-644. [CrossRef] [PubMed]

6. Maier, R.M. Bioavailability and Its Importance to Bioremediation. In Bioremediation; Valdes, J.J., Ed.; Springer: Dordrecht, The Netherlands, 2000; pp. 59-78, ISBN 978-94-015-9425-7.

7. Megharaj, M.; Ramakrishnan, B.; Venkateswarlu, K.; Sethunathan, N.; Naidu, R. Bioremediation approaches for organic pollutants: A critical perspective. Environ. Int. 2011, 37, 1362-1375. [CrossRef] [PubMed]

8. Ren, X.; Zeng, G.; Tang, L.; Wang, J.; Wan, J.; Liu, Y.; Yu, J.; Yi, H.; Ye, S.; Deng, R. Sorption, transport and biodegradation-An insight into bioavailability of persistent organic pollutants in soil. Sci. Total Environ. 2018, 610-611, 1154-1163. [CrossRef] [PubMed]

9. Zeng, Z.; Liu, Y.; Zhong, H.; Xiao, R.; Zeng, G.; Liu, Z.; Cheng, M.; Lai, C.; Zhang, C.; Liu, G.; et al. Mechanisms for rhamnolipids-mediated biodegradation of hydrophobic organic compounds. Sci. Total Environ. 2018, 634, 1-11. [CrossRef] [PubMed]

10. Pereira, J.F.B.; Gudiña, E.J.; Costa, R.; Vitorino, R.; Teixeira, J.A.; Coutinho, J.A.P.; Rodrigues, L.R. Optimization and characterization of biosurfactant production by Bacillus subtilis isolates towards microbial enhanced oil recovery applications. Fuel 2013, 111, 259-268. [CrossRef]

11. Bajaj, A.; Mayilraj, S.; Mudiam, M.K.R.; Patel, D.K.; Manickam, N. Isolation and functional analysis of a glycolipid producing Rhodococcus sp. strain IITR03 with potential for degradation of 1,1,1-trichloro2,2-bis(4-chlorophenyl)ethane (DDT). Bioresour. Technol. 2014, 167, 398-406. [CrossRef] [PubMed]

12. Antoniou, E.; Fodelianakis, S.; Korkakaki, E.; Kalogerakis, N. Biosurfactant production from marine hydrocarbon-degrading consortia and pure bacterial strains using crude oil as carbon source. Front. Microbiol. 2015, 6, 274. [CrossRef] [PubMed]

13. Santos, D.; Rufino, R.; Luna, J.; Santos, V.; Sarubbo, L. Biosurfactants: Multifunctional biomolecules of the 21st century. Int. J. Mol. Sci. 2016, 17, 401. [CrossRef] [PubMed]

14. Mnif, I.; Chaabouni, S.E.; Ghribi, D. Glycolipid Biosurfactants, Main Classes, Functional Properties and Related Potential Applications in Environmental Biotechnology. J. Polym. Environ. 2018, 26, 2192-2206. [CrossRef]

15. Mukherjee, A.K.; Das, K. Microbial Surfactants and Their Potential Applications: An Overview. Biosurfactants 2010, 672, 54-64.

16. Pacwa-Płociniczak, M.; Płaza, G.A.; Piotrowska-Seget, Z.; Cameotra, S.S. Environmental applications of biosurfactants: Recent advances. Int. J. Mol. Sci. 2011, 12, 633-654. [CrossRef] [PubMed]

17. Mnif, I.; Ghribi, D. Lipopeptides biosurfactants: Mean classes and new insights for industrial, biomedical, and environmental applications. Biopolymers 2015, 104, 129-147. [CrossRef] [PubMed]

18. Irfan-Maqsood, M.; Seddiq-Shams, M. Rhamnolipids: Well-Characterized Glycolipids with Potential Broad Applicability as Biosurfactants. Ind. Biotechnol. 2014, 10, 4. [CrossRef]

19. Fakruddin, M. Biosurfactant: Production and Application. J. Pet. Environ. Biotechnol. 2012, 3, 124. [CrossRef]

20. Ali, S.; Hameed, S.; Imran, A.; Iqbal, M.; Lazarovits, G. Genetic, physiological and biochemical characterization of Bacillus sp. strain RMB7 exhibiting plant growth promoting and broad spectrum antifungal activities. Microb. Cell Fact. 2014, 13, 144. [CrossRef] [PubMed]

21. Passed, A.; Lang, S.; Wagner, F.; Wray, V. Marine Biosurfactants, II. Production and Characterization of an Anionic Trehalose Tetraester from the Marine Bacterium Arthrobacter sp. EK 1. Zeitschrift für Naturforschung C 2014, 46, 204-209.

22. Bezza, F.A.; Chirwa, E.M.N. Bioremediation of Polycyclic Aromatic Hydrocarbon Contaminated Soil by a Microbial Consortium through Supplementation of Biosurfactant Produced by Pseudomonas aeruginosa Strain. Polycycl. Aromat. Compd. 2016, 36. [CrossRef]

23. Franzetti, A.; Tamburini, E.; Banat, I.M. Applications of Biological Surface Active Compounds in Remediation Technologies. Biosurfactants 2010, 672, 121-134. 
24. Singh, R.; Glick, B.R.; Rathore, D. Biosurfactants as a Biological Tool to Increase Micronutrient Availability in Soil: A Review. Pedosphere 2018, 28, 170-189. [CrossRef]

25. Noordman, W.H.; Wachter, J.H.J.; De Boer, G.J.; Janssen, D.B. The enhancement by surfactants of hexadecane degradation by Pseudomonas aeruginosa varies with substrate availability. J. Biotechnol. 2002, 94, 195-212. [CrossRef]

26. Patowary, K.; Patowary, R.; Kalita, M.C.; Deka, S. Development of an Efficient Bacterial Consortium for the Potential Remediation of Hydrocarbons from Contaminated Sites. Front. Microbiol. 2016, 7, 1092. [CrossRef] [PubMed]

27. Jemil, N.; Hmidet, N.; Ben Ayed, H.; Nasri, M. Physicochemical characterization of Enterobacter cloacae C3 lipopeptides and their applications in enhancing diesel oil biodegradation. Process Saf. Environ. Prot. 2018, 117, 399-407. [CrossRef]

28. Schippers, C.; Geßner, K.; Müller, T.; Scheper, T. Microbial degradation of phenanthrene by addition of a sophorolipid mixture. J. Biotechnol. 2000, 83, 189-198. [CrossRef]

29. Wang, B.; Wang, Q.; Liu, W.; Liu, X.; Hou, J.; Teng, Y.; Luo, Y.; Christie, P. Chemosphere Biosurfactantproducing microorganism Pseudomonas sp. SB assists the phytoremediation of DDT-contaminated soil by two grass species. Chemosphere 2017, 182, 137-142. [CrossRef] [PubMed]

30. Mnif, I.; Sahnoun, R.; Ellouze-chaabouni, S. Evaluation of B. subtilis SPB1 biosurfactants' potency for diesel-contaminated soil washing: Optimization of oil desorption using Taguchi design. Environ. Sci. Pollut. 2014, 21, 851-861. [CrossRef] [PubMed]

31. Lamichhane, S.; Krishna, K.C.B.; Sarukkalige, R. Surfactant-enhanced remediation of polycyclic aromatic hydrocarbons: A review. J. Environ. Mana. 2017, 199, 46-61. [CrossRef] [PubMed]

32. Attwood, D.; Florence, A.T. Surfactant Systems: Their Chemistry, Pharmacy and Biology, Aspects of Surfactant Toxicity; Chaman \& Hall: London, UK, 1983.

33. Kaczorek, E.; Urbanowicz, M.; Olszanowski, A. The influence of surfactants on cell surface properties of Aeromonas hydrophila during diesel oil biodegradation. Colloid Surf. B 2010, 81, 363-368. [CrossRef] [PubMed]

34. Bueno-Montes, M.; Springael, D.; Ortega-Calvo, J.J. Effect of a nonionic surfactant on biodegradation of slowly desorbing PAHs in contaminated soils. Environ. Sci. Technol. 2011, 45, 3019-3026. [CrossRef] [PubMed]

35. Paria, S. Surfactant-enhanced remediation of organic contaminated soil and water. Adv. Colloids Interface Sci. 2008, 138, 24-58. [CrossRef] [PubMed]

36. Zhu, H.; Aitken, M.D. Surfactant-enhanced desorption and biodegradation of polycyclic aromatic hydrocarbons in contaminated soil. Environ. Sci. Technol. 2010, 44, 7260-7265. [CrossRef] [PubMed]

37. Wang, Z. Bioavailability of organic compounds solubilized in nonionic surfactant micelles. Appl. Microbiol. Biotechnol. 2011, 89, 523-534. [CrossRef] [PubMed]

38. Hua, F.; Wang, H.Q. Uptake and trans-membrane transport of petroleum hydrocarbons by microorganisms. Biotechnol. Biotechnol. Equip. 2014, 28, 165-175. [CrossRef] [PubMed]

39. Seo, Y.; Bishop, P.L. Influence of nonionic surfactant on attached biofilm formation and phenanthrene bioavailability during simulated surfactant enhanced bioremediation. Environ. Sci. Technol. 2007, 41, 7107-7113. [CrossRef] [PubMed]

40. Kar, T.; Destain, J.; Thonart, P.; Delvigne, F. Scale-down assessment of the sensitivity of Yarrowia lipolytica to oxygen transfer and foam management in bioreactors: Investigation of the underlying physiological mechanisms. J. Ind. Microbiol. Biotechnol. 2012, 39, 337-346. [CrossRef] [PubMed]

41. Rafati Atri, M.; Ashrafizadeh, S.N. The importance of foams and antifoaming in bioprocesses. Pak. J. Biotechnol. 2010, 7, 19-39.

42. Luna, J.M.; Rufino, R.D.; Sarubbo, L.A.; Campos-Takaki, G.M. Characterisation, surface properties and biological activity of a biosurfactant produced from industrial waste by Candida sphaerica UCP0995 for application in the petroleum industry. Colloid Surf. B 2013, 102, 202-209. [CrossRef] [PubMed]

43. Suganthi, S.H.; Murshid, S.; Sriram, S.; Ramani, K. Enhanced biodegradation of hydrocarbons in petroleum tank bottom oil sludge and characterization of biocatalysts and biosurfactants. J. Environ. Manag. 2018, 220, 87-95. [CrossRef] [PubMed]

44. Jemil, N.; Ben Ayed, H.; Hmidet, N.; Nasri, M. Characterization and properties of biosurfactants produced by a newly isolated strain Bacillus methylotrophicus DCS1 and their applications in enhancing solubility of hydrocarbon. World J. Microbiol. Biotechnol. 2016, 32, 175. [CrossRef] [PubMed] 
45. Ma, K.Y.; Sun, M.Y.; Dong, W.; He, C.Q.; Chen, F.L.; Ma, Y.L. Effects of nutrition optimization strategy on rhamnolipid production in a Pseudomonas aeruginosa strain DN1 for bioremediation of crude oil. Biocatal. Agric. Biotechnol. 2016, 6, 144-151. [CrossRef]

46. Peele, K.A.; Ch, V.R.T.; Kodali, V.P. Emulsifying activity of a biosurfactant produced by a marine bacterium. 3 Biotech. 2016, 6, 1-6. [CrossRef] [PubMed]

47. Costa, S.G.V.A.O.; Nitschke, M.; Lépine, F.; Déziel, E.; Contiero, J. Structure, properties and applications of rhamnolipids produced by Pseudomonas aeruginosa L2-1 from cassava wastewater. Process Biochem. 2010, 45, 1511-1516. [CrossRef]

48. Lee, D.W.; Lee, H.; Kwon, B.O.; Khim, J.S.; Yim, U.H.; Kim, B.S.; Kim, J.J. Biosurfactant-assisted bioremediation of crude oil by indigenous bacteria isolated from Taean beach sediment. Environ. Pollut. 2018, 241, 254-264. [CrossRef] [PubMed]

49. Mohanty, S.; Mukherji, S. Surfactant aided biodegradation of NAPLs by Burkholderia multivorans: Comparison between Triton X-100 and rhamnolipid JBR-515. Colloid Surf. B 2013, 102, 644-652. [CrossRef] [PubMed]

50. Ma, Z.; Liu, J.; Dick, R.P.; Li, H.; Shen, D.; Gao, Y.; Waigi, M.G.; Ling, W. Rhamnolipid influences biosorption and biodegradation of phenanthrene by phenanthrene-degrading strain Pseudomonas sp. Ph6. Environ. Pollut. 2018, 240, 359-367. [CrossRef] [PubMed]

51. Congiu, E.; Ortega-Calvo, J. Role of Desorption Kinetics in the Rhamnolipid-Enhanced Biodegradation of Polycyclic Aromatic Hydrocarbons. Environ. Sci. Technol. 2014, 48, 10869-10877. [CrossRef] [PubMed]

52. Bezza, F.A.; Chirwa, E.M.N. The role of lipopeptide biosurfactant on microbial remediation of aged polycyclic aromatic hydrocarbons (PAHs)-contaminated soil. Chem. Eng. J. 2017, 309, 563-576. [CrossRef]

53. Bezza, F.A.; Nkhalambayausi-Chirwa, E.M. Desorption kinetics of polycyclic aromatic hydrocarbons (Pahs) from contaminated soil and the effect of biosurfactant supplementation on the rapidly desorbing fractions. Biotechnol. Biotechnol. Equip. 2015, 29, 680-688. [CrossRef]

54. Yao, Y.; Huang, G.H.; An, C.J.; Cheng, G.H.; Wei, J. Effects of freeze-thawing cycles on desorption behaviors of PAH-contaminated soil in the presence of a biosurfactant: A case study in western Canada. Environ. Sci. Proc. Imp. 2017, 19, 874-882. [CrossRef]

55. Crampon, M.; Cebron, A.; Portet-Koltalo, F.; Uroz, S.; Le Derf, F.; Bodilis, J. Low effect of phenanthrene bioaccessibility on its biodegradation in diffusely contaminated soil. Environ. Pollut. 2017, 225, 663-673. [CrossRef] [PubMed]

56. Yu, H.; Huang, G.H.; Xiao, H.; Wang, L.; Chen, W. Combined effects of DOM and biosurfactant enhanced biodegradation of polycylic armotic hydrocarbons (PAHs) in soil-water systems. Environ. Sci. Pollut. Res. 2014, 21, 10536-10549. [CrossRef] [PubMed]

57. Liu, Y.; Yang, S.F.; Li, Y.; Xu, H.; Qin, L.; Tay, J.H. The influence of cell and substratum surface hydrophobicities on microbial attachment. J. Biotechnol. 2004, 110, 251-256. [CrossRef] [PubMed]

58. Liu, G.; Zhong, H.; Yang, X.; Liu, Y.; Shao, B.; Liu, Z. Advances in applications of rhamnolipids biosurfactant in environmental remediation: A review. Biotechnol. Bioeng. 2018, 115, 796-814. [CrossRef] [PubMed]

59. Silva-Dias, A.; Miranda, I.M.; Branco, J.; Monteiro-Soares, M.; Pina-Vaz, C.; Rodrigues, A.G. Adhesion, biofilm formation, cell surface hydrophobicity, and antifungal planktonic susceptibility: Relationship among Candida spp. Front Microbiol. 2015, 6, 205. [CrossRef] [PubMed]

60. Rosenberg, M.; Gutnick, D.; Rosenberg, E. Adherence of bacteria to hydrocarbons: A simple method for measuring cell-surface hydrophobicity. FEMS Microbiol. Lett. 1980, 9, 29-33. [CrossRef]

61. Krasowska, A.; Sigler, K. How microorganisms use hydrophobicity and what does this mean for human needs? Front. Cell. Infect. Microbiol. 2014, 4, 112. [CrossRef] [PubMed]

62. Kaczorek, E.; Smułek, W.; Zdarta, A.; Sawczuk, A.; Zgoła-Grześkowiak, A. Influence of saponins on the biodegradation of halogenated phenols. Ecotoxicol. Environ. Saf. 2016, 131, 127-134. [CrossRef] [PubMed]

63. Gallardo-Moreno, A.M.; Navarro-Pérez, M.L.; Vadillo-Rodríguez, V.; Bruque, J.M.; González-Martín, M.L. Insights into bacterial contact angles: Difficulties in defining hydrophobicity and surface Gibbs energy. Colloid Surf. B 2011, 88, 373-380. [CrossRef] [PubMed]

64. Van der Mei, H.C.; Bos, R.; Busscher, H.J. A reference guide to microbial cell surface hydrophobicity based on contact angles. Colloid Surf. B 1998, 11, 213-221. [CrossRef] 
65. Zhang, D.; Zhu, L.; Li, F. Influences and mechanisms of surfactants on pyrene biodegradation based on interactions of surfactant with a Klebsiella oxytoca strain. Bioresour. Technol. 2013, 142, 454-461. [CrossRef] [PubMed]

66. Lin, W.; Liu, S.; Tong, L.; Zhang, Y.; Yang, J.; Liu, W.; Guo, C.; Xie, Y.; Lu, G.; Dang, Z. Effects of rhamnolipids on the cell surface characteristics of Sphingomonas sp. GY2B and the biodegradation of phenanthrene. RSC Adv. 2017, 7, 24321-24330. [CrossRef]

67. Kaczorek, E.; Olszanowski, A. Uptake of hydrocarbon by Pseudomonas fluorescens (P1) and Pseudomonas putida (K1) strains in the presence of surfactants: A cell surface modification. Water Air Soil Pollut. 2011, 214, 451-459. [CrossRef] [PubMed]

68. Zhao, Z.; Selvam, A.; Wong, J.W.-C. Effects of rhamnolipids on cell surface hydrophobicity of PAH degrading bacteria and the biodegradation of phenanthrene. Bioresour. Technol. 2011, 102, 3999-4007. [CrossRef] [PubMed]

69. Rizzo, C.; Rappazzo, A.C.; Michaud, L.; De Domenico, E.; Rochera, C.; Camacho, A.; Lo Giudice, A. Efficiency in hydrocarbon degradation and biosurfactant production by Joostella sp. A 8 when grown in pure culture and consortia. J. Environ. Sci. 2018, 67, 115-126. [CrossRef] [PubMed]

70. Reddy, P.V.; Karegoudar, T.B.; Nayak, A.S. Enhanced utilization of fluorene by Paenibacillus sp. PRNK-6: Effect of rhamnolipid biosurfactant and synthetic surfactants. Ecotoxicol. Environ. Saf. 2018, 151, $206-211$. [CrossRef] [PubMed]

71. Al-Tahhan, R.A.; Sandrin, T.R.; Bodour, A.A.; Maier, R.M. Rhamnolipid-induced removal of lipopolysaccharide from Pseudomonas aeruginosa: Effect on cell surface properties and interaction with hydrophobic substrates. Appl. Environ. Microbiol. 2000, 66, 3262-3268. [CrossRef] [PubMed]

72. Bai, N.; Wang, S.; Abuduaini, R.; Zhang, M.; Zhu, X.; Zhao, Y. Rhamnolipid-aided biodegradation of carbendazim by Rhodococcus sp. D-1: Characteristics, products, and phytotoxicity. Sci. Total Environ. 2017, 590-591, 343-351. [CrossRef] [PubMed]

73. Sotirova, A.V.; Spasova, D.I.; Galabova, D.N.; Karpenko, E.; Shulga, A. Rhamnolipid-biosurfactant permeabilizing effects on gram-positive and gram-negative bacterial strains. Curr. Microbiol. 2008, 56, 639-644. [CrossRef] [PubMed]

74. Sotirova, A.; Spasova, D.; Vasileva-Tonkova, E.; Galabova, D. Effects of rhamnolipid-biosurfactant on cell surface of Pseudomonas aeruginosa. Microbiol. Res. 2009, 164, 297-303. [CrossRef] [PubMed]

75. Hua, Z.; Chen, J.; Lun, S.; Wang, X. Influence of biosurfactants produced by Candida antarctica on surface properties of microorganism and biodegradation of n-alkanes. Water Res. 2003, 37, 4143-4150. [CrossRef]

76. Sze, A.; Erickson, D.; Ren, L.; Li, D. Zeta-potential measurement using the Smoluchowski equation and the slope of the current-time relationship in electroosmotic flow. J. Colloid Interface Sci. 2003, 261, 402-410. [CrossRef]

77. Martienssen, M.; Reichel, O.; Kohlweyer, U. Surface Properties of Bacteria from Different Wastewater Treatment Plants. Acta Biotechnol. 2001, 21, 207-225. [CrossRef]

78. Kaczorek, E. Effect of External Addition of Rhamnolipids Biosurfactant on the Modification of Gram Positive and Gram Negative Bacteria Cell Surfaces during Biodegradation of Hydrocarbon Fuel Contamination. Polish J. Environ. Stud. 2012, 21, 901-909.

79. Soni, K.A.; Balasubramanian, A.K.; Beskok, A.; Pillai, S.D. Zeta potential of selected bacteria in drinking water when dead, starved, or exposed to minimal and rich culture media. Curr. Microbiol. 2008, 56, 93-97. [CrossRef] [PubMed]

80. Zhou, C.; Wang, F.; Chen, H.; Li, M.; Qiao, F.; Liu, Z.; Hou, Y.; Wu, C.; Fan, Y.; Liu, L.; et al. Selective Antimicrobial Activities and Action Mechanism of Micelles Self-Assembled by Cationic Oligomeric Surfactants. ACS Appl. Mater. Interface 2016, 8, 4242-4249. [CrossRef] [PubMed]

81. Koley, D.; Bard, A.J. Triton X-100 concentration effects on membrane permeability of a single HeLa cell by scanning electrochemical microscopy (SECM). Proc. Natl. Acad. Sci. USA 2010, 107, 16783-16787. [CrossRef] [PubMed]

82. Mohanty, S.; Jasmine, J.; Mukherji, S. Practical considerations and challenges involved in surfactant enhanced bioremediation of oil. Biomed Res. Int. 2013, 2013, 328608. [CrossRef] [PubMed]

83. Ivanković, T.; Hrenović, J. Surfactants in the environment. Arch. Ind. Hyg. Toxicol. 2010, 61, 95-110.

84. Scott, M.J.; Jones, M.N. The biodegradation of surfactants in the environment. Biochim. Biophys. Acta 2000, 1508, 235-251. [CrossRef] 
85. Shao, B.; Liu, Z.; Zhong, H.; Zeng, G.; Liu, G.; Yu, M.; Liu, Y.; Yang, X.; Li, Z.; Fang, Z.; et al. Effects of rhamnolipids on microorganism characteristics and applications in composting: A review. Microbiol. Res. 2017, 200, 33-44. [CrossRef] [PubMed]

86. Sperandeo, P.; Lau, F.K.; Carpentieri, A.; De Castro, C.; Molinaro, A.; Deho, G.; Silhavy, T.J.; Polissi, A. Functional Analysis of the Protein Machinery Required for Transport of Lipopolysaccharide to the Outer Membrane of Escherichia coli. J. Bacteriol. 2008, 190, 4460-4469. [CrossRef] [PubMed]

87. Bharali, P.; Saikia, J.P.; Ray, A.; Konwar, B.K. Rhamnolipid (RL) from Pseudomonas aeruginosa OBP1: A novel chemotaxis and antibacterial agent. Colloid Surf. B 2013, 103, 502-509. [CrossRef] [PubMed]

88. De Aguiar Cordeiro, R.; Weslley Caracas Cedro, E.; Raquel Colares Andrade, A.; Serpa, R.; José de Jesus Evangelista, A.; Sales de Oliveira, J.; Santos Pereira, V.; Pereira Alencar, L.; Bruna Leite Mendes, P.; Cibelle Soares Farias, B.; et al. Inhibitory effect of a lipopeptide biosurfactant produced by Bacillus subtilis on planktonic and sessile cells of Trichosporon spp. Biofouling 2018, 34, 309-319. [CrossRef] [PubMed]

89. Sana, S.; Datta, S.; Biswas, D.; Sengupta, D. Assessment of synergistic antibacterial activity of combined biosurfactants revealed by bacterial cell envelop damage. Biochim. Biophys. Acta 2018, 1860, 579-585. [CrossRef] [PubMed]

90. Vasileva-Tonkova, E.; Sotirova, A.; Galabova, D. The effect of rhamnolipid biosurfactant produced by Pseudomonas fluorescens on model bacterial strains and isolates from industrial wastewater. Curr. Microbiol. 2011, 62, 427-433. [CrossRef] [PubMed]

91. Vasileva-Tonkova, E.; Galabova, D.; Karpenko, E.; Shulga, A. Biosurfactant-rhamnolipid effects on yeast cells. Lett. Appl. Microbiol. 2001, 33, 280-284. [CrossRef] [PubMed]

92. Dusane, D.H.; Dam, S.; Nancharaiah, Y.V.; Kumar, A.; Venugopalan, V.P.; Zinjarde, S.S. Disruption of Yarrowia lipolytica biofilms by rhamnolipid biosurfactant. Aquat. Biosyst. 2012, 8, 17. [CrossRef] [PubMed]

93. Carrillo, C.; Teruel, J.A.; Aranda, F.J.; Ortiz, A. Molecular mechanism of membrane permeabilization by the peptide antibiotic surfactin. Biochim. Biophys. Acta 2003, 1611, 91-97. [CrossRef]

94. Kim, L.H.; Jung, Y.; Kim, S.-J.; Kim, C.-M.; Yu, H.-W.; Park, H.-D.; Kim, I.S. Use of rhamnolipid biosurfactant for membrane biofouling prevention and cleaning. Biofouling 2015, 31, 211-220. [CrossRef] [PubMed]

95. Zaragoza, A.; Aranda, F.J.; Espuny, M.J.; Teruel, J.A.; Marqués, A.; Manresa, Á.; Ortiz, A. Mechanism of Membrane Permeabilization by a Bacterial Trehalose Lipid Biosurfactant Produced by Rhodococcus sp. Langmuir 2009, 25, 7892-7898. [CrossRef] [PubMed]

96. Smułek, W.; Zdarta, A.; Pacholak, A.; Zgoła-Grześkowiak, A.; Marczak, Ł.; Jarzębski, M.; Kaczorek, E. Saponaria officinalis L. extract: Surface active properties and impact on environmental bacterial strains. Colloid Surf. B 2017, 150, 209-215. [CrossRef] [PubMed]

97. Zdarta, A.; Dudzińska-Bajorek, B.; Nowak, A.; Guzik, U.; Kaczorek, E. Impact of potent bioremediation enhancing plant extracts on Raoultella ornithinolytica properties. Ecotoxicol. Environ. Saf. 2017, 145, 274-282. [CrossRef] [PubMed]

98. Ortiz, A.; Teruel, J.A.; Manresa, Á.; Espuny, M.J.; Marqués, A.; Aranda, F.J. Effects of a bacterial trehalose lipid on phosphatidylglycerol membranes. Biochim. Biophys. Acta 2011, 1808, 2067-2072. [CrossRef] [PubMed]

99. Amro, N.A.; Kotra, L.P.; Wadu-Mesthrige, K.; Bulychev, A.; Mobashery, S.; Liu, G. High-Resolution Atomic Force Microscopy Studies of the Escherichiacoli Outer Membrane: Structural Basis for Permeability. Langmuir 2000, 16, 2789-2796. [CrossRef]

100. Kallimanis, A.; Frillingos, S.; Drainas, C.; Koukkou, A.I. Taxonomic identification, phenanthrene uptake activity, and membrane lipid alterations of the PAH degrading Arthrobacter sp. strain Sphe3. Appl. Microbiol. Biotechnol. 2007, 76, 709-717. [CrossRef] [PubMed]

101. Murínová, S.; Dercová, K.; Čertík, M.; Lászlová, K. The adaptation responses of bacterial cytoplasmic membrane fluidity in the presence of environmental stress factors-Polychlorinated biphenyls and 3-chlorobenzoic acid. Biologia (Bratisl) 2014, 69. [CrossRef]

102. Li, F.; Zhu, L. Surfactant-modified fatty acid composition of Citrobacter sp. SA01 and its effect on phenanthrene transmembrane transport. Chemosphere 2014, 107, 58-64. [CrossRef] [PubMed]

103. Tecon, R.; Van Der Meer, J.R. Effect of two types of biosurfactants on phenanthrene availability to the bacterial bioreporter Burkholderia sartisoli strain RP037. App. Microbiol. Biotechnol. 2010, 84, 1131-1139. [CrossRef] [PubMed]

104. Otzen, D.E. Biosurfactants and surfactants interacting with membranes and proteins: Same but different? Biochim. Biophys. Acta 2017, 1859, 639-649. [CrossRef] [PubMed] 
105. Sánchez, M.; Aranda, F.J.; Teruel, J.A.; Espuny, M.J.; Marqués, A.; Manresa, Á.; Ortiz, A. Permeabilization of biological and artificial membranes by a bacterial dirhamnolipid produced by Pseudomonas aeruginosa. J. Colloid Interface Sci. 2010, 341, 240-247. [CrossRef] [PubMed]

106. Heipieper, H.J.; Neumann, G.; Cornelissen, S.; Meinhardt, F. Solvent-tolerant bacteria for biotransformations in two-phase fermentation systems. Appl. Microbiol. Biotechnol. 2007, 74, 961-973. [CrossRef] [PubMed]

107. Cai, Z.; Kastell, A.; Knorr, D.; Smetanska, I. Exudation: An expanding technique for continuous production and release of secondary metabolites from plant cell suspension and hairy root cultures. Plant Cell Rep. 2012, 31, 461-477. [CrossRef] [PubMed]

108. Yuniati, M.D. Bioremediation of petroleum-contaminated soil: A Review. IOP Conf. Ser. Earth Environ. Sci. 2018, 118, 012063. [CrossRef]

109. Mao, X.; Jiang, R.; Xiao, W.; Yu, J. Use of surfactants for the remediation of contaminated soils: A review. J. Hazard. Mater. 2015, 285, 419-435. [CrossRef] [PubMed]

110. Zhong, H.; Liu, G.; Jiang, Y.; Yang, J.; Liu, Y.; Yang, X.; Liu, Z.; Zeng, G. Transport of bacteria in porous media and its enhancement by surfactants for bioaugmentation: A review. Biotechnol. Adv. 2017, 35, 490-504. [CrossRef] [PubMed]

111. Perfumo, A.; Smyth, T.J.P.; Marchant, R.; Banat, I.M. Production and roles of biosurfactants and bioemulsifiers in accessing hydrophobic substrates. In Handbook of Hydrocarbon and Lipid Microbiology; Timmis, K.N., Ed.; Springer: Berlin Heidelberg, Germany, 2010; pp. 1501-1512.

112. Zhang, G.; Wu, Y.; Qian, X.; Meng, Q. Biodegradation of crude oil by Pseudomonas aeruginosa in the presence of rhamnolipids. J. Zhejiang Univ. Sci. 2005, 6B, 725-730. [CrossRef] [PubMed]

113. Zhang, Y.; Miller, R.M. Effect of rhamnolipid (biosurfactant) structure on solubilization and biodegradation of n-alkanes. Appl. Environ. Microbiol. 1995, 61, 2247-2251. [PubMed]

114. Bramwell, D.A.P.; Laha, S. Effects of surfactant addition on the biomineralization and microbial toxicity of phenanthrene. Biodegradation 2000, 11, 263-277. [CrossRef] [PubMed]

115. Urum, K.; Pekdemir, T. Evaluation of biosurfactants for crude oil contaminated soil washing. Chemesphere 2004, 57, 1139-1150. [CrossRef] [PubMed]

116. Ghosh, I.; Mukherji, S. Diverse effect of surfactants on pyrene biodegradation by a Pseudomonas strain utilizing pyrene by cell surface hydrophobicity induction. Int. Biodeterior. Biodegrad. 2016, 108, 67-75. [CrossRef]

117. Tian, W.; Yao, J.; Liu, R.; Zhu, M.; Wang, F.; Wu, X.; Liu, H. Effect of natural and synthetic surfactants on crude oil biodegradation by indigenous strains. Ecotoxicol. Environ. Saf. 2016, 121, 171-179. [CrossRef] [PubMed]

118. Thavasi, R.; Jayalakshmi, S.; Banat, I.M. Application of biosurfactant produced from peanut oil cake by Lactobacillus delbrueckii in biodegradation of crude oil. Bioresour. Technol. 2011, 102, 3366-3372. [CrossRef] [PubMed]

119. Sobrinho, H.B.S.; Rufino, R.D.; Luna, J.M.; Salgueiro, A.A.; Campos-Takaki, G.M.; Leite, L.F.C.; Sarubbo, L.A. Utilization of two agroindustrial by-products for the production of a surfactant by Candida sphaerica UCP0995. Process Biochem. 2008, 43, 912-917. [CrossRef]

120. Shavandi, M.; Mohebali, G.; Haddadi, A.; Shakarami, H.; Nuhi, A. Emulsification potential of a newly isolated biosurfactant-producing bacterium, Rhodococcus sp. strain TA6. Colloid Surf. B 2011, 82, 477-482. [CrossRef] [PubMed]

121. Beal, R.; Betts, W.B. Role of rhamnolipid biosurfactants in the uptake and mineralization of hexadecane in Pseudomonas aeruginosa. J. Appl. Microbiol. 2000, 89, 158-168. [CrossRef] [PubMed]

122. Zeng, G.; Liu, Z.; Zhong, H.; Li, J.; Yuan, X.; Fu, H.; Ding, Y.; Wang, J.; Zhou, M. Effect of monorhamnolipid on the degradation of n-hexadecane by Candida tropicalis and the association with cell surface properties. Appl. Microbiol. Biotechnol. 2011, 90, 1155-1161. [CrossRef] [PubMed]

123. Rahman, K.S.M.; Rahman, T.J.; Kourkoutas, Y.; Petsas, I.; Marchant, R.; Banat, I.M. Enhanced bioremediation of n-alkane in petroleum sludge using bacterial consortium amended with rhamnolipid and micronutrients. Bioresour. Technol. 2003, 90, 159-168. [CrossRef]

124. Zhang, H.F.; Yang, X.H.; Wang, Y. Microwave assisted extraction of secondary metabolites from plants: Current status and future directions. Trends Food Sci. Technol. 2011, 22, 672-688. [CrossRef] 
125. Whang, L.M.; Liu, P.W.G.; Ma, C.C.; Cheng, S.S. Application of rhamnolipid and surfactin for enhanced diesel biodegradation-Effects of $\mathrm{pH}$ and ammonium addition. J. Hazard. Mater. 2009, 164, 1045-1050. [CrossRef] [PubMed]

126. Guo, Q.; Yan, J.; Wen, J.; Hu, Y.; Chen, Y.; Wu, W. Rhamnolipid-enhanced aerobic biodegradation of triclosan (TCS) by indigenous microorganisms in water-sediment systems. Sci. Total Environ. 2016, 571, 1304-1311. [CrossRef] [PubMed]

127. Singh, P.; Singh, H.; Raj, M. Ecotoxicology and Environmental Safety Rhamnolipid mediated enhanced degradation of chlorpyrifos by bacterial consortium in soil-water system. Ecotoxicol. Environ. Saf. 2016, 134, 156-162. [CrossRef] [PubMed]

128. Price, N.P.J.; Ray, K.J.; Vermillion, K.E.; Dunlap, C.A.; Kurtzman, C.P. Structural characterization of novel sophorolipid biosurfactants from a newly identified species of Candida yeast. Carbohydr. Res. 2012, 348, $33-41$. [CrossRef] [PubMed]

129. Kang, S.W.; Kim, Y.B.; Shin, J.D.; Kim, E.K. Enhanced biodegradation of hydrocarbons in soil by microbial biosurfactant, sophorolipid. Appl. Biochem. Biotechnol. 2010, 160, 780-790. [CrossRef] [PubMed]

130. Almeida, D.G.; Soares da Silva, R.D.C.F.; Brasileiro, P.P.F.; de Luna, J.M.; Da Silva, M.D.G.C.; Rufino, R.D.; Costa, A.F.S.; Santos, V.A.; Sarubbo, L.A. Application of a biosurfactant from Candida tropicalis ucp 0996 produced in low-cost substrates for hydrophobic contaminants removal. Chem. Eng. Trans. 2018, 64, 541-546. [CrossRef]

131. Sajna, K.V.; Sukumaran, R.K.; Gottumukkala, L.D.; Pandey, A. Crude oil biodegradation aided by biosurfactants from Pseudozyma sp. NII 08165 or its culture broth. Bioresour. Technol. 2015, 191, 133-139. [CrossRef] [PubMed]

132. Bustamante, M.; Durán, N.; Diez, M.C. Biosurfactants are useful tools for the bioremediation of contaminated soil: A review. J. Soil Sci. Plant Nutr. 2012, 12, 667-687. [CrossRef]

133. Swaathy, S.; Kavitha, V.; Pravin, A.S.; Mandal, A.B.; Gnanamani, A. Microbial surfactant mediated degradation of anthracene in aqueous phase by marine Bacillus licheniformis MTCC 5514. Biotechnol. Rep. 2014, 4, 161-170. [CrossRef] [PubMed]

134. McKew, B.A.; Coulon, F.; Yakimov, M.M.; Denaro, R.; Genovese, M.; Smith, C.J.; Osborn, A.M.; Timmis, K.N.; McGenity, T.J. Efficacy of intervention strategies for bioremediation of crude oil in marine systems and effects on indigenous hydrocarbonoclastic bacteria. Environ. Microbiol. 2007, 9, 1562-1571. [CrossRef] [PubMed]

135. Pei, X.H.; Zhan, X.H.; Wang, S.M.; Lin, Y.S.; Zhou, L.X. Effects of a Biosurfactant and a Synthetic Surfactant on Phenanthrene Degradation by a Sphingomonas Strain. Pedosphere 2010, 20, 771-779. [CrossRef]

136. Nazari, M.; Kurdi, M.; Heerklotz, H. Classifying Surfactants with Respect to Their Effect on Lipid Membrane Order. Biophys. J. 2012, 102, 498-506. [CrossRef] [PubMed]

137. Kowalewski, E.; Rueslåtten, I.; Steen, K.H.; Bødtker, G.; Torsæter, O. Microbial improved oil recoveryBacterial induced wettability and interfacial tension effects on oil production. J. Pet. Sci. Eng. 2006, 52, 275-286. [CrossRef]

138. Kuppusamy, S.; Thavamani, P.; Venkateswarlu, K.; Lee, Y.B.; Naidu, R.; Megharaj, M. Remediation approaches for polycyclic aromatic hydrocarbons (PAHs) contaminated soils: Technological constraints, emerging trends and future directions. Chemosphere 2017, 168, 944-968. [CrossRef] [PubMed]

139. Zhu, Z.; Zhang, B.; Chen, B.; Cai, Q.; Lin, W. Biosurfactant Production by Marine-Originated Bacteria Bacillus Subtilis and Its Application for Crude Oil Removal. Water. Air. Soil Pollut. 2016, 227. [CrossRef]

140. Vilela, W.F.D.; Fonseca, S.G.; Oliveira, V.M.; Nitschke, M. Production and Properties of a Surface-Active Lipopeptide Produced by a New Marine Brevibacterium luteolum Strain. Appl. Biochem. Biotechnol. 2014, 2245-2256. [CrossRef] [PubMed]

141. Pacheco, G.J.; Ciapina, E.M.P.; de Barros Gomes, E.; Pereira Junior, N. Biosurfactant production by Rhodococcus erythropolis and its application to oil removal. Braz. J. Microbiol. 2010, 41, 685-693. [CrossRef] [PubMed]

142. Makkar, R.S.; Cameotra, S.S. Biosurfactant production by microorganisms on unconventional carbon sources. J. Surfactants Deterg. 1999, 2, 237-241. [CrossRef]

(C) 2018 by the authors. Licensee MDPI, Basel, Switzerland. This article is an open access article distributed under the terms and conditions of the Creative Commons Attribution (CC BY) license (http:/ / creativecommons.org/licenses/by/4.0/). 